\title{
Behavioral and Comparative Analysis of the Information Paradigm in Consumer Law
}

\author{
Tatia Nikvashvili \\ New Vision University, LLM Student, \\ Lawyer at Georgian National Competition Agency
}

\section{ARTICLE INFO}

Article History:

Received 29.10.2021

Accepted 10.11.2021

Published 20.12.2021

\section{Keywords:}

Behavioral Law and Economics, Informing Consumers, Consumer Credit

\section{ABSTRACT}

This article examines the issue of information asymmetry in consumer law and deliberates on the necessity of regulation of the status of a consumer and their protection mechanisms. It is evident that the relevant Georgian law, by and large, does not guarantee the sufficient safeguarding level and thus the approximation to the respective EU legislation cannot be deemed successful in toto. Furthermore, this article analyzes the Draft Law of Georgia on the Protection of Consumer Rights and displays the possible challenges. In addition, the special emphasis is on consumer credit contracts.

In the wake of the growing importance of behavioral analysis and its impact on the law and economics, the standard of an informed and rational consumer, which constitutes a cornerstone of the EU consumer law, is now highly debated. By reviewing some findings in behavioral law and economics, along with the international legislation and case law, it is argued that some implications of behavioralism should be taken into account in the field of consumer law. 


\section{INTRODUCTION}

In consumer relations, which is centered on the protection of consumer rights, information asymmetry ${ }^{1}$ constitutes one of the major issues, that is, incorrectly exchanged and perceived information lays the basis for the market decline or failure. To eliminate its consequences, different jurisdictions turn to legal and regulatory intervention, one of which is the requirement to disclose information. In contrast to the general obligation to provide information under the contract law, the obligation to disclose information in consumer contracts is regulated separately, based on the formal, abstract idea of equality, which in turn portrays the leading image of a rational consumer with economic interests ${ }^{2}$, who is free from paternalism ${ }^{3}$. Today such a paradoxical image of the consumer is a matter of debate since the consumer, due to the various factors, is not always rational, nevertheless, the consumer in the field of law is recognized as a "weak party"4, thus is subjected to the special safeguarding legislation.

In the legal literature and case law ${ }^{5}$ there is a discussion on the irrationality of the consumer while facing a choice. In this regard, behavioral analysis plays an important role, given that the interpretation of information by the consumer is ultimately an empirical issue ${ }^{6}$. Consumer law is one of the first areas where lawyers have become aware of the relevance of behavioral insights ${ }^{7}$. This, on the one hand, stems

1 Information asymmetry is a situation when one party of a relationship has more information on a subject matter than the other and thus is in a more powerful position. See Chang, H.-J., 2014. Economics: The User's Guide, London, Penguin, p. 391 E.g. See C-59/12, BKK Mobil Oil Korperschaft des offentlichen Rechts v Zentrale zur Bekampfung unlauteren Wettbewerbs eV [2013]

Dani, M., 2011. Assembling The Fractured European Consumer, LEQS 29, p. 13, however, there are some viable arguments supporting the paternalistic approach to protecting consumers, e.g., see Haupt, S., 2003. An Economic Analysis of Consumer Protection in Contract Law, German Law Journal, 4(11), p. 1161.

This approach is constitutionally recognized. See Decision No. 1/3/136 of the Constitutional Court of Georgia of 30 December 2002, paragraph 10 .

5 See C-382/87, Buet v Ministère Public [1989] ECR 1235.

6 Beales, J.H., 2008. Consumer Protection and Behavioral Economics: To BE or Not to BE? Competition Policy International, p. 165.

7 Sibony, A.L., Helleringer, G., 2015. EU Consumer Protection and Behavioural Sciences: Revolution or from the fact that consumer law focuses on individual behavior, and, on the other hand, it is naturally paternalistic as it aims to protect consumers from negative choices. Consequently, the role of behavioral sciences in that sense is to offer the types of regulation that will be better for the consumers and civil circulation. In consumer relations, such a goal is achieved by tools like information disclosure ${ }^{8}$ and cooling-off period.

Unlike the approach under the conventional economic analysis, which usually determines outcomes "as if' people behave optimally ${ }^{9}$, behavioral approach takes into account the actual behavior of consumers with the help of researches in neuroscience or psychology ${ }^{10}$. It shows that a person has weak self-control and limited rationality when making a choice ${ }^{11}$, moreover, behavioral science offers a very important idea that consumers cannot and do not want to make an informed choice about everything ${ }^{12}$. Therefore, many countries establish relevant behavioural entities that inductively address various regulatory issues. As far as the topic of consumer relations is concerned, it is noteworthy that similar institutions are found directly in consumer rights administrations, such as the Directorate-General for Justice and Consumers in the EU, the FTC in the US, the Authority for Consumers and Market in the Netherlands, etc. ${ }^{13}$. Hence, this topic is timely as the consumer rights issues are very dynamic.

On June 27, 2014, the Association Agreement was signed between Georgia and the European Union, which entered into force on July 1, 2016.
8
Reform? Nudge and The Law, Hart Publishing, p. 209.

Pre-contractual obligation to provide and disclose information.

Australian Government Productivity Commission, 2008. Review of Australia's Consumer Policy Framework, Final Report, p. 383.

See Calabresi, G., 2016. The Future of Law and Economics, Yale University Press, p. 5.

Bounded Rationality refers to the situation when people fail to consider all of the possible alternatives and longterm consequences before making economic decisions. See, Simon H.A., 1957, Rational Choice and the Structure of the Environment, in Models of man: social and rational; New York, Wiley, p. 198.

Sunstein, C., 2015. Choosing not to Choose: Understanding the Value of Choice, Oxford University Press.

See OECD Science, Technology and Industry Policy Papers, 2017. Use of Behavioural Insights in Consumer Policy, No. 36, OECD Publishing, Paris, p. 10. 
With this, Georgia has committed itself to the approximation to EU legislation. One of the important packages of this agreement, in particular Chapter 13 of Title $\mathrm{VI}$, deals with the protection of consumer rights. In this vein, the Committee on European Integration of the Parliament of Georgia has developed a draft law ${ }^{14}$ on consumer protection [Hereinafter - the Draft Law], which will be examined in the relevant context in this article. Unfortunately, the adoption of this draft law has so far failed for a variety of reasons. It should also be noted that the Association Agreement refers to the repealed or amended EU directives, while the article is based on the consolidated and existing texts.

Furthermore, special attention shall be paid to the pre-contractual obligation to disclose information in the consumer credit contracts. It shall be emphasized that financial transactions require special regulation and it is of importance for the legislator to tread gingerly in order not to cause double regulation $^{15}$

\section{IMAGE OF THE CONSUMER AND THE INFORMATION PARADIGM}

In order to ensure a high level of consumer protection, it is necessary to create and understand the image of the consumer itself. In turn, this requires an explanation of the information paradigm that forms the basis of the consumer image.

The information paradigm constitutes a traditional fundamental feature of EU consumer law, which is laid down in many directives ${ }^{16}$. It suggests that on the one hand, there are consumers who are able, willing, and competent to deal with the information provided, to read different languages, to make informed rational decisions, and to en-

14 Draft Law of Georgia on the Protection of Consumer Rights, $2019 \quad$ https://info.parliament.ge/file/1/ BillReviewContent/224285?

Micklitz, H. W., 2018. Legal Opinion of the Draft Law of Georgia on the Protection of Consumer Rights (As of March 2017), Comparative legal studies, \#6, GIZ, pp. 7-8. force their information-based rights ${ }^{17}$. On the other hand, the information paradigm ensures that in a consumer contract it is an obligation of a trader to provide information ${ }^{18}$ due to the information advantage. The standard of the average consumer relies heavily on the image of homo economicus, the rational consumer. In various decisions of the European Court of Justice, the average consumer is reasonably well-informed and reasonably observant and circumspect ${ }^{19}$. However, this is not fully in line with empirical studies, otherwise, such a buyer would not be seriously affected by the so-called no-reading tendency ${ }^{20}$. Pursuant to this presumption, such a consumer should check all the information and read the labels ${ }^{21}$, should not be deceived by the color of the product, etc. However, behavioral studies have shown that there is in fact a large discrepancy between the EU's idealized average consumer and the actual behaviour adopted by the average EU consumers ${ }^{22}$.

Indeed, if we share the conventional economic analysis that individuals make choices to maximize their utility using the information available, while their preferences are consistent through time $^{23}$, we will contradict the market reality and, most importantly, the concept of the consumer as a "weak party"24. In particular, the objective "weakness" of the consumer is that he is in a vulnerable position in relation to the informed trader with

17 Micklitz, H.W., Reisch, L.A., Hagan, K., 2011. An Introduction to the Special Issue on "Behavioural Economics, Consumer Policy, and Consumer Law", Springer, p. 271.

18 Lakerbaia, T., 2015. European Standard for Informed Consumer, Journal of Law N1, Tbilisi State University Publishing (in Georgian), p. 147.

19 First mentioned in C-210/96, Gut Springerheide [1998] EU:C:1998:369 [31] and then in a number of cases, e.g. C 611/14, Canal Digital Danmark [2016] EU:C:2016:800 [39].

20 Aryes, I., Schwartz, A., 2014. The No-Reading Problem in Consumer Contract Law, Stanford Law Review, Vol. 66 No.3. Such apathy is also considered rational, see BenShahar, O., 2009. The Myth of the "Opportunity to Read" in Contract Law, European Review of Contract Law, p. 5.

21 Case C-51/94, Commission v Germany [1995] EU:C:1995:352 [34] when the court decided that the consumers, who do care about the ingredients read the labels.

22 Ibid, n.7, p. 215.

23 Kennedy, S., 2008. The future of consumer policy: Should we regulate to protect homo economicus? Competition and Consumer Policy Division, Australian Treasury, p. 10.

24 Ibid, n.4. al (eds), European Consumer Law Cambridge, p. 21. For example, Directive 2005/29/EC; Directive 2011/83/EU. 
some market power and marketing policy, while the subjective "weakness" conveys the personal characteristics of consumers, e.g., hesitation and influence on free will often lead to undesirable results ${ }^{25}$. Simply put, using product packaging to increase the value of a product makes it clear that consumers should not be perceived as rational. Moreover, even in B2B relationships, where the expected level of rationality is high, emotional factors have a significant impact even on qualified professionals ${ }^{26}$.

It is noteworthy that some EU member states rely on the irrational image of the consumer. For instance, Scandinavian national consumer law does not envisage an "average" consumer benchmark in the legislation, which is resulted in the formation of a type of "weak", "vulnerable" consumers and a higher standard of their protection $^{27}$. Nevertheless, according to the Supreme Court of Finland, as a result of the full harmonization of the Unfair Commercial Practices Directive 2005/29/EC, when applicable, the traditional image of the irrational consumer goes backward and the court relies on the EU average consumer standard $^{28}$. Meanwhile, studies in modern economics, psychology, and neuroscience have also revealed that the information paradigm is a symbol of consumer law in modern England ${ }^{29}$. Thus, it is obvious that some countries recognize the importance of behavioural economics. Therefore, as discussed below, it is necessary to integrate the behavioral insights into the information paradigm, which serves the freedom of choice.

Lakerbaia, T., Zaalishvili, V., Zoidze, T., 2018. Consumer Law, IBSU Publishing. (in Georgian), p. 49.

26 Hague, P., A Guide to B2B Marketing And How it Differs From Consumer Marketing, https://www.b2binternational. com/publications/b2b-marketing/[26.10.2021]

27 Hyvöven, S., 2019. Information Obligations and Disinformation of Consumers: Finnish Law Report, Springer, p. 411.

28 Finnish Supreme Court Decision KKO 2017:83, when the court decided that despite taking into consideration the social, cultural and linguistic factors pursuant to rec.18 of the Directive, there was no reason to regard the Finnish consumers as less informed and less observant and circumspect.

29 Bush, C., 2016. The Future of Pre-Contractual information Duties: From Behavioural Insights to Big Data, Research Handbook on EU Consumer and Contract Law, p. 221.

\section{DISCLOSURE OF INFORMATION TO CONSUMERS WITH BOUNDED RATIONALITY}

\subsection{The need for regulation and cognitive biases}

The fulfillment of choice is twofold: one is about ensuring fair competition and the other is about having the right information, without which the ignorance of an alternative hinders the ability to make a choice. Undistorted competition, with low prices, wide choice, high quality and innovation, serves to optimize the interests of consumers, and consumer protection law guarantees that the result of competition is authentic and a real choice ${ }^{30}$. Thus, with different approaches, these two areas of law create a framework for the market that is essential to the growth of productivity and consumer welfare ${ }^{31}$.

The obligation to provide information at the pre-contractual stage serves an important function of protecting consumers from information asymmetry and enhancing consumer choice. This is one of the fundamental regulatory tools ${ }^{32}$ in the EU for eliminating inequality between the parties and is defined in almost every directive as a specific protection mechanism to which, in some cases, other mechanisms are attached ${ }^{33}$.

The economic analysis of the disclosure of information for the protection of the rights of consumers lies in the fact that the benefits of the consumer, reflected in the coherent choices, should exceed the administrative or other costs of such regulatory intervention ${ }^{34}$. Therefore, the consumer should be able to make a "good contract". ${ }^{35}$

30 De Pree, J., 2019. Trends: anti-trust, consumer and privacy regulation increasingly converge, https://www.debrauw. com/legalarticles/trends-anti-trust-consumer-and-privacyregulation-increasingly-converge/ [26.10.2021]

31 Huffman, M., 2010. Bridging the Divide? Theories for Integrating Competition law and Consumer Protection, European Competition Journal, April, p. 7.

32 Wilhelmsson, T., \& Twigg-Flesner, C., 2006. Precontractual information duties in the acquis communautaire. European review of contract law : ERCL., 2(4), pp. 441470.

33 Ibid, n. 25, p. 124.

34 Haupt, S., 2003, An Economic Analysis of Consumer Protection in Contract Law, German Law Journal, 4(11), p. 1142.

35 Grynbaum, L., 2010. Pre-contractual Information Duties: the foreseeable failure of full harmonisation, Prospectives 
In addition, although providing accurate information in a simple, understandable manner is in the best interests of market players in order to attract consumers, in practice the regulatory intervention is still needed ${ }^{36}$. In this regard, the different standard of disclosure of information in distance contracts is especially noteworthy, which was further developed by the new Directive 2019/2161 ${ }^{37}$ and became adapted to the existing reality. This example also proves that behavioral analysis is very relevant in consumer law.

Behavioral science distinguishes various "biases" that should be considered in policy-making. Different types of cognitive biases ultimately create the notion of bounded rationality. In particular, consumers due to the optimism bias ${ }^{38}$ are characterized by inadequate risk assessment. Apart from that, they prematurely refuse to obtain information about the contract to be concluded on the grounds that they are intuitively confident in being sufficiently informed or, because of a status quo bias ${ }^{39}$ they are intimidated by the information overload. ${ }^{40}$

\subsection{Avoiding "blinding lights" - the optimal level of information}

Empirical studies in neuroscience have shown that the perception and processing of a large amount and very detailed information by humans is limited due to cognitive skills. ${ }^{41}$ It was pointed out that the

of European Consumer Law, Towards a Directive on Consumer Rights and Beyond, Schulte-Nölke, H., Tichŷ, L., (eds.), Sellier, p. 7. Ibid, n.6, p.163.

37 This Directive amends both Directive 2011/83 / EU and Directive 2005/29 / EC. Member States have until 28 November 2021 to implement the amendments in national laws.

Tendency to overestimate our chances of positive experiences and underestimate our chances of negative experiences.

39 When maintaining the status quo seems better than to change it.

40 Dean, M., Kibris, O., Masatlioglu, Y., 2017. Limited attention and status quo bias. Journal of Economic Theory, pp. 93-127.

41 Klingberg, T., 2009. The Overflowing Brain: Information Overload and the Limits of Working Memory, Oxford University Press, also, directly on consumers - Lee, B.K., and Lee, W.N., 2004, The Effect of Information Overload on Consumer Choice Quality in an On-Line Environment, Psychology \& Marketing, p. 159. more information is, it becomes tall order to process the relevant information in order to profit from it ${ }^{42}$. In this vein a metaphor of being blinded by the light is used to depict such a maximum level of information $^{43}$. Given the limited time factor, consumers turn to heuristics ${ }^{44}$, observe key group indicators, also known as chunks, such as price or brand, and do not spend time searching for new products, or, as a consequence, we get the Buridan donkey paradox when they are reluctant to make a decision. Thus, it is obvious that information overload reduces the marginal utility of information, and efficiency. Finding the optimal margin in various types of consumer contracts will be different, hence the importance of empirical studies in this regard is of high value. ${ }^{45}$ Nevertheless, the consumer should always have the right to request more information.

Furthermore, the necessary information should be simple, concise, clear and easily comprehensible. In the EU, prior to the entry into force of Directive 2011/83/ EU, traders in certain cases were required to provide only some specific information. Directive 2011/83/EU established for the first time the general obligation of traders to provide information in accordance with Article 5. Article 6 sets out the obligation to provide information only for the distance and off-premises contracts. It is noteworthy that the latter article is criticized for the abundance of precontractual information, and the timing of information is considered to be a solution, when the meaning is given to the context. ${ }^{46}$ Criticism is particularly relevant when it comes to a low-cost product. On the other hand, the new Directive 2019/2161 offers a significant change in the obligation to disclose information whether the seller is a trader or an ordinary individual because in the latter case the consumer must be warned of the lack of protection under consumer law in advance ${ }^{47}$.

42 Djurovic, M., 2016. The Duty of Information. European Law on Unfair Commercial Practices and Contract Law, Oxford: Hart Publishing, p. 139.

43 Paredes, T., 2003. Blinded by the Light: Information Overload and its Consequences for Securities Regulation, Washington University Law Quarterly, 81(2), p. 417.

44 In most situations consumers are biased towards information that is easily accessible and more up-to-date. Ibid, n. 34.

46 Ibid, n. 7, p. 221, in particular, the consumer may be less interested in where and how to return the product before concluding the contract.

47 Recitals 26 and 27 of the Directive 2011/83/EU. 
As for the Georgian reality, the requirement to disclose information can be found in various normative acts, in particular, in Article 318 of the Civil Code of Georgia; in Article 12 of the Product Safety and Free Circulation Code, which is the general regulation. However, the scope of the latter code is less relevant to the contractual aspects and is primarily aimed at protecting "human life, health, property and the environment". Thus, the regulation is less in line with European legislation. Further, the Law on Advertising sets out the criteria for lawful advertising through putting information on a product. However, this legal regime does not meet the criteria of "relevance" or "completeness". ${ }^{48}$

Some novelties of the Draft Law of Georgia on the Protection of Consumer Rights are in line with the standard of Directive 2011/83/EU. Article 5 and Article 11, respectively, envisage the general rules on consumer information and rules for distance and off-premises contracts. According to Article 5 of the Draft Law, the consumer has the right to receive, and the trader is obliged to provide information about the product name, identity of a trader, terms of consumer claim, manufacturing and expiration dates, the total price of the product, arrangement of payments, delivery and warranty conditions, functionality, contract duration, consumer obligations, and the right of withdrawal. Under Article 11, the consumer must also be provided with information on communication costs, and the existence of a code of conduct.

It is noteworthy that the amendments in the newest draft law have corrected some of the shortcomings, e.g. the previous draft law did not specify the obligation to provide information before concluding a contract, as well as regarding no obligation to provide information that is already apparent. Both articles, de lege ferenda, clearly state that the trader must provide the information in a vivid and understandable manner before concluding the contract. Nevertheless, against the criterion of relevance, the draft law does not impose an obligation on traders to provide information at different stages and to a different extent. It should be stated that due to the nonexistence of a general law on consumer rights in Georgia, traders in most of their business areas are not obliged to disclose information. As a corollary, the new regulations may lead to a number of short-

48

„John Howard Test”. comings and thus increase the price of the product, with the risk of having information overload. Therefore, it is more efficient to disclose the information regarding the product description, warranty, and return policy at the pre-contractual stage, and the rest of the information after signing the contract. It is also suggested to update the relevant provisions in line with the amendments in Directive 2019/2161, such as the removal of a fax, or the removal of an obligation to provide a waiver form when a distance means are used for contracting in an insufficient time and space.

Another important provision is Article 25 that regulates unfair commercial practices and complies with the complex rules of Directive 2005/29. Here, it should be noted that this provision, unlike the previous version, introduces the notion of an average consumer. Behavioral analysis and the regulatory impact assessment ${ }^{49}$ show that the starting point for the protection of consumer rights should be the vulnerable rather than the average consumer due to political, economic and social reasons in Georgia ${ }^{50}$. Similar approach is taken in the policy of Bulgaria, Greece and other countries, which shall also be considered in Georgia before giving the Draft Law its legal effect.

\section{COOLING-OFF PERIODS AND RIGHT OF WITHDRAWAL}

In addition to the general obligation to disclose information, the right to cancel a contract is considered as a tool to protect consumers from the negative consequences of asymmetric information. Different jurisdictions provide the so-called mandatory cooling-off periods, within which the consumer, in some circumstances, especially in distance or off-premises contracts, is given some time after the conclusion of the contract to check the aptness of the choice. This is considered in Article 9 of Directive 2011/83/EU, which is aimed at protecting the consumer from psychological pressure, as well as avoiding the negative consequences ${ }^{51}$ of providing inappropriate information. By the same token, Arti-

\footnotetext{
49 Regulatory Impact Assessment on the Draft Law of Georgia on Consumer Rights Protection, 2019. GIZ.

$50 \quad$ Ibid, p. 58.

51 Ibid, n. 17, p. 160
} 
cle 9 encourages consumers to compare the product. This possibility is more limited in distance relationships. Thus, in addition to the characteristics of the product, the consumer must be informed about the cooling-off period and its application conditions.

The existence of a cooling-off period is justified when it constitutes a necessary means of eliminating inefficiency ${ }^{52}$. This issue may arise due to the lack of rationality, and the cooling-off period should nudge a consumer to take heed of the long-term preferences, beyond the pressure and so-called situational monopoly. The existence of the right of withdrawal gives the trader the incentive to match the price of the product with its quality, although it should be noted that this right may as well encourage ex post opportunistic behavior from consumers, leading to tension in traders, increased transaction costs due to delays and ambiguity. ${ }^{53}$

Behavioral analysis makes it obvious that the status quo bias, the endowment effect ${ }^{54}$, loss aversion $^{55}$ and regret aversion ${ }^{56}$, and the sunk cost falla$\mathrm{cy}^{57}$ can encourage behaviors that hinder the effective exercise of the right of withdrawa ${ }^{58}$. In order to prevent this, the "opt-in" rule ${ }^{59}$ is introduced, that is, instead of the withdrawal from the contractual relationship, the consumer actively gives consent only after the expiration of the cooling-off period. This would reduce the cognitive dissonance to some extent, however, it is highly likely that such regulation

Ibid, n. 34, p. 1147.

Ibid, p. 1149.

The endowment effect leads consumers to place a greater value on objects once they have established ownership, or a sense of ownership than the value they would place on that same object if they did not own it.

55 The tendency to prefer avoiding losses to acquiring equivalent gains. See Kahneman, D., Tversky, A., 1979. Prospect theory: An analysis of decision under risk, Vol. 47, The Econometric Society, pp. 263-291.

Consumers have a fear that they will regret the choice to exercise the right of return, which they consider when making a decision.

57 According to traditional economic theory, such costs are not relevant in future decisions, although studies show that people still take them into account. Sunk cost fallacy is an attachment to past decisions, even when wrong.

58 Tscherner, E.M., 2014. Can behavioral research advance mandatory law, information duties, standard terms and withdrawal rights? Austrian Law Journal, p. 155.

Ibid, p. 154. Also, Harrison, P., 2016. Cooling-off periods for consumers don't work: study https://theconversation. com/cooling-off-periods-for-consumers-dont-workstudy-69473 [26.10.2021]. would complicate the trade relations and would not mitigate some of the biases, thus it is of importance to empirically analyze the consequences of such changes.

Article 336 of the Civil Code of Georgia recognizes the right to cancel a doorstep contract when the consumer has the right to withdraw the contract within one week unless the contract is performed upon its conclusion. An important update is made in Article 14 of the Draft Law, which gives the consumer the right to cancel a distance or off-premises contract within 14 calendar days, with a maximum return period of 7 days. This right also provides for a number of exceptions per se via Article 16, however it shall be stressed that the previous version of the Draft Law, unlike to current one, extended the 7-day cooling-off period to an on-premises contract. This modification stems from the regulatory impact assessments ${ }^{60}$, which have shown the likely negative consequences of such regulation for businesses and the threat of transition to the shadow economy. Thus, the change in the draft law on withdrawal rights should be positively assessed taking into account the level of socio-economic development, consumer vulnerability and the growing trend of online shopping.

\section{SPECIAL REGULATION - CONSUMER CREDIT CONTRACT}

The financial sector constitutes a distinctive field in the consumer markets, in particular, the contracts of the consumer credit, related consumer rights and guarantees for the protection of these rights are regulated separately. In the EU, there are two major directives in this field - Directive 2008/48/EC on Consumer Credit and Directive 2002/65/EC on Distance Marketing of Financial Services, which in turn was amended by Directive 2005/29/EC. The latter clarifies in Articles 9 and 10 that issues related to financial services can be regulated more strictly by member states due to their complexity and high risks.

Behavioral analysis is especially relevant when consumers while receiving complex information, do $60 \quad$ RIA, $\quad$ http://www.moesd.gov.ge/uploads/publications/
economy_450476725899caab552165.56302821.pdf
[26.10.2021]. 
not have adequate practical experience. In this vein, it is logical for the legislator to have a specific regulation on the consumer credit. The reason for justification for having such an approach is that the financial risks are very high for the average consumer, and there is little opportunity for learning due to the slow feedback mechanism ${ }^{61}$.

In terms of providing information, it shall be emphasized again that the consumers should not be overloaded by complex information to the extent that they should be able to properly assess the risks. Considering the behavioral analysis, several aspects are worth noting:

The consumers need to be provided with the information on the effective interest rate in advance to have a real opportunity for the proper comparison. Furthermore, in order to achieve transparency, financial institutions should calculate the effective interest rate based on the uniform standard, and the calculation should include all of the financial costs. Prevention of over-indebtedness and over-optimism of consumers can be prevented by using heuristics, in particular by focusing on risks; Special attention should be drawn to the variable interest rate, which implies more risk for the consumer than the fixed interest rate ${ }^{62}$; Consumers may be provided with the information by financial institutions on the statistics of non-payment in typical cases. It is noteworthy that the directive envisages a cooling-off period of 14 days for the consumer credit contracts.

According to the Georgian legislative framework, the National Bank of Georgia with its regulatory and supervisory functions constitutes a designated authority for ensuring the protection of the rights of consumers in the financial sector. Currently, the Order of the President of the National Bank №37/0463 of 2021 on the Approval of the Rule of Protection of Consumers' Rights in the Provision of Services by Financial Organizations [the Order] is in effect, which was adopted subsequent to the repeal of the previous order. The number of changes

61 Juurikkala, O., 2013. The New Legal Paternalism: LightTouch Regulation for Consumer Mortgages, Helsinki Law Review, 7, pp. 55-84, p. 58.

62 Ibid, p. 72.

63 The Order of the President of the National Bank №37/04 on the Approval of the Rule of Protection of Consumers' Rights in the Provision of Services by Financial Organizations. https://matsne.gov.ge/ka/document/view/5117792?publicati on $=0 \#$ DOCUMENT:1 enshrined in the order aim at enhancing the level of protection of the rights of consumers, for instance, the scope of the act is no longer limited, thus any lending entity is obliged to provide the consumer with the precontractual information specified in the order. It should also be noted that the notion of a specific financial product no longer forms a grey area. ${ }^{64}$ On the other hand, the issue of the effective accountability mechanism for the violation of consumer rights needs separate research.

Pursuant to Order No. 32/04 both natural persons and legal entities, except for financial organizations, are entitled to be provided with information. This precontractual obligation to fully disclose the information leads to a stable, transparent and predictable legal relationship ${ }^{65}$. The very first article of the Order enshrines the principles applicable to the disclosure of information similar to the European model: a) clarity and accuracy; B) perceptibility; C) ability to compare and d) timeliness. This provision also focuses on the consistency of information disclosure, however, the accuracy criterion is less obvious and is presented only in the subsequent provisions. Freedom of choice is provided by Article 3 , according to which the information must be such as not to push the consumers towards a decision which they would not have made in case of the unmistakable and complete information.

The notion of an effective interest rate shall also be stipulated due to its wide scope. It is noted that this rate includes all the financial costs, and the annex of the Order that regulates its calculation rules and formula aims at ensuring a common standard and transparency. The main method of calculation is to "use the highest interest rate", while in foreign currency lending 15\% annual depreciation of GEL is considered based on the variations of the equal absolute of the exchange rate on a daily basis. According to the Order, the disclosure of the effective interest rate is provided both during the advertisement and during the personal offer ${ }^{66}$. This is significant insofar as it is the only means of protecting the consumer, taking the Georgian lending policy into account.

As mentioned above, Article 3 of the Order, which sets out the obligation for financial institutions

\begin{tabular}{ll}
\hline 64 & Ibid, n. 63, Art 2(n) \\
65 & Ibid, n. 25, p. 113. \\
66 & Ibid, n. 63, Art. 3.15; Art. 4.
\end{tabular}


to provide information, does not clarify the content of the information. This is specified in the article on concluding a distance contract. In Annex 5, the Order provides the sample version of the text of disclosure. In order to improve the comprehensibility, it would be more practical to divide the text into several paragraphs or bullet points. Further, Article 5 of the Order is of importance as it obliges a financial institution to provide information to consumers regarding the significant risks associated with the specific financial products, including drawing attention to the variable interest rate risk. ${ }^{67}$

At the advertising stage, pursuant to the Order, disclosure of incorrect or misleading information is prohibited. In addition, when the effective interest rate is unclear from the outset due to the uncertainty of costs, based on the sample example in Annex 6 of the Order, the option to refer to the disclosure of the minimum effective interest rate (for example, from $20.8 \%$ ) is expressed. In this regard, a different treatment is provided in the $\mathrm{EU}$, such as the use of the cognitive bias, namely, the framing effect ${ }^{68}$ by referencing to the maximum amount of percentage. ${ }^{69}$

Further, It should be noted that the Order, unlike the Directive, does not provide for the right of withdrawal, which does not allow the consumer to reconsider the offer while being labeled as vulnerable in this sector (and generally in Georgia). On the other hand, the order of the President of the National Bank №37/04 provides for the possibility of canceling a foreign exchange transaction within 30 minutes after the transaction. ${ }^{70}$ This may constitute an issue as the Draft Law's provisions of the cooling-off period only apply to distance and off-premises contracts, and according to the sphere of its application the Draft Law does not extend to financial services other than the standard terms, hence this issue remains the subject of future regulation, as well as unfair commercial practices in the financial sector.

Finally, pursuant to Part II Article 625 of the Civ-

$67 \quad$ Ibid, Art. 5.3.

68 Consumers are influenced not only by the content of the information but also by the way the information is delivered, its form, and arrangement.

69 Behavioural Insights Applied to Policy, European Report 2016, pp. 20-21. https://publications.jrc.ec.europa.eu/ repository/bitstream/JRC100146/kjna27726enn_new.pdf https://matsne.gov.ge/ka/document/ view/4081097?publication $=6$ Consolidated text: 14.07.2021. il Code of Georgia the maximum annual effective interest rate of the loan is reduced to 50 percent. A similar regulation is relevant in other countries, for instance, with the changes made in Finland in 2019 , this mark is 20 percent, moreover, the legislative initiative envisages a temporary reduction of the interest rate on certain types of consumer loans to 10 percent. ${ }^{71}$ The Credit Card Accountability Responsibility and Disclosure (CARD) Act is in place in the United States, which, similar to Georgian regulations, sets the maximum interest rate for the financial institutions and thus prevents the possible misuse of cognitive biases of the consumers by the financial sector. ${ }^{72}$

\section{Conclusion}

The information paradigm still constitutes a pertinent issue in the consumer protection law, and the behavioral analysis, stemming from the empirical research, further suggests the necessity to protect even a well-informed consumer. It is widely acknowledged that freedom of choice is one of the cornerstones of consumer law, yet the problem of information overload and the cognitive, time-related or environmental factors that influence the consumer when making a choice prevent its effective exercise. As a corollary, it makes sense to disclose the information not all at once, but at different stages.

The integration of behavioural insights into the consumer law would not constitute a revolution per $\mathrm{se}^{73}$, given that for many years both the private and public sectors have been closely monitoring consumer behavior and considering it in practice. Nevertheless, the article analyzes some aspects that need to be modified. However, the legal reality in Georgia is disparate as the deregulation of the consumer market has led to an unequal legal relationship between the trader and the consumer, recognized as a weak party. ${ }^{74}$ To this extent, considering that the initiated Draft Law already offers

71 Waselius and Wist, New temporary restrictions on interest rates and direct marketing of consumer loans. https://www. ww.fi/news/2020/04/new-temporary-restrictions-on-interest-rates-and-direct-marketing-of-consumer-loans/ [26.10.2021].

72 Ibid, n.13, p. 28.

73 Ibid, n.7, p. 212.

74 Ibid, n. 49, p. 4. 
many innovations and there is practically no general regulation in this area, it is noted that this regulation will already bring significant changes for the consumer and business sectors in Georgia. Nonetheless, it should be stressed that the new regulation should not put the onus on MSMEs. In this vein, it is suggested that instead of mandatory provisions, the guidelines for the disclosure of information at the precontractual stage might be introduced. On the other hand, it is necessary to encourage consumers to exercise their rights in order to highlight their preferences based on the relevant market practice. It should be noted that the standard of the average consumer in Georgia should be equal to the standard of the vulnerable consumer, which would highlight the essential parts and nuances of the general regulation. Hence, it will be possible to avoid the unjustified increase in traders' costs that would ultimately affect the price of the product. Furthermore, the state should actively engage to raise the standard of the consumer ${ }^{75}$, and develop an effective and scrupulous action plan, which would include the activities aimed at raising consumer awareness.
As shown in this article, the special regulations envisage the standard of disclosure of information, including the Order of the President of the National Bank. Notwithstanding the important provisions of the Draft Law, it is interesting to follow its effects on the consumer credit contract, considering that the latter will be subjected to the new chapter on the standard terms of the Draft Law, as well as the Order of the National Bank and the relevant articles of the Civil Code of Georgia. On the one hand, it is of importance to avoid double regulation, and on the other hand, to improve the regulation of commercial practices by making appropriate changes in the normative acts in the financial sector.

Finally, it should be stressed that the law cannot factor into the context of consumer decisions with the same precision and scale as the psychology suggests, however, in order to improve consumer welfare, the state should consider the key findings of behavioral economics in case it leads to lowering the costs. In this vein, the regulatory impact assessments play a salient role, as shown in the analysis of the two draft versions of the law.

75 E.g. the standard of a "reasonable consumer'

BIBLIOGRAPHY:

1. Aryes, I., Schwartz, A., 2014. The No-Reading Problem in Consumer Contract Law, Stanford Law Review, Vol. 66, No.3

2. "Association Agreement between the European Union and the European Atomic Energy Community and their Member states, of on the one part, and Georgia, of the other part". https://matsne.gov.ge/ka/document/view/2496959?publication=0 (in Georgian)

3. Beales, J.H., 2008. Consumer Protection and Behavioral Economics: To BE or Not to BE?, Competition Policy International 4(1)

4. Behavioural Insights Applied to Policy, European Report 2016. https://publications. irc.ec.europa.eu/repository/bitstream/JRC100146/kjna27726enn new.pdf

5. Ben-Shahar, O., 2009. The Myth of the "Opportunity to Read" in Contract Law, European Review of Contract Law, vol. 5, no. 1

6. Bush, C., 2016. The Future of Pre-Contractual information Duties: From Behavioural Insights to Big Data, Research Handbook on EU Consumer and Contract Law, Edward Elgar Publishing, Chapter 10

7. C-210/96 Gut Springerheide, EU:C:1998:369

8. Calabresi G., 2016. The Future of Law and Economics, Yale University Press

9. Canal Digital Danmark, C 611/14, EU:C:2016:800

10. Case C-382/87, Buet v Ministère Public [1989] ECR 1235

11. Case C-59/12 BKK Mobil Oil Korperschaft des offentlichen Rechts v Zentrale zur Bekampfung unlauteren Wettbewerbs eV [2013] 
12. Chang, H.-J., 2014. Economics: The User's Guide, London, Penguin

13. Civil Code of Georgia, as of December 2021

14. Dani, M., 2011. Assembling The Fractured European Consumer, LEQS Paper No. 29

15. De Pree, J., 2019. Trends: anti-trust, consumer and privacy regulation increasingly converge. https://www. debrauw.com/legalarticles/trends-anti-trust-consumer-and-privacy-regulation-increasingly-converge/ [25.10.2021]

16. Dean, M., Kibris, O., Masatlioglu, Y., 2017. Limited attention and status quo bias. Journal of Economic Theory, Elsevier, vol. 169(C)

17. Directive (EU) 2019/2161 of the European Parliament and of the Council of 27 November 2019 amending Council Directive 93/13/EEC and Directives 98/6/EC, 2005/29/EC and 2011/83/EU of the European Parliament and of the Council as regards the better enforcement and modernisation of Union consumer protection rules (Text with EEA relevance)

18. Directive 2002/65/EC of the European Parliament and of the Council of 23 September 2002 concerning the distance marketing of consumer financial services

19. Directive 2005/29/EC of the European Parliament and of the Council of 11 May 2005 concerning unfair business-to-consumer commercial practices in the internal market

20. Directive 2008/48/EC of the European Parliament and of the Council of 23 April 2008 on credit agreements for consumers

21. Directive 2011/83/EU of the European Parliament and of the Council of 25 October 2011 on consumer rights

22. Djurovic, M., 2016. The Duty of Information. European Law on Unfair Commercial Practices and Contract Law, Oxford: Hart Publishing

23. Draft Law of Georgia on the Protection of Consumer Rights, 2019. https://info.parliament.ge/file/1/BillReviewContent/224285?

24. Finnish Supreme Court Decision KKO 2017:83

25. Grynbaum, L., 2010. Pre-contractual information duties: the foreseeable failure of full harmonization. In H. Schulte-Nölke \& L. Tichy (Ed.), Perspectives for European Consumer Law: Towards a Directive on Consumer Rights and Beyond. Berlin, New York: Otto Schmidt/De Gruyter European law publishers

26. Hague, P., A Guide to B2B Marketing And How it Differs From Consumer Marketing. https://www.b2binternational.com/publications/b2b-marketing/ [26.10.2021]

27. Harrison, P., 2016. Cooling-off periods for consumers don't work: study. https:// theconversation.com/cooling-off-periods-for-consumers-dont-work-study-69473 [26.10.2021]

28. Haupt, S., 2003. An Economic Analysis of Consumer Protection in Contract Law, German Law Journal, 4(11)

29. Huffman, M., 2010. Bridging the Divide? Theories for Integrating Competition law and Consumer Protection, European Competition Journal, vol. 6

30. Hyvöven, S., 2019. Information Obligations and Disinformation of Consumers: Finnish Law Report. In Straetmans. G., (Ed.), Information Obligations and Disinformation of Consumers (lus Comparatum - Global Studies in Comparative Law; Vol. 33)

31. Juurikkala, O., 2013. The New Legal Paternalism: Light-Touch Regulation for Consumer Mortgages, Helsinki Law Review, 7

32. Kahneman, D., Tversky, A,. 1979. Prospect Theory: An Analysis of Decision Under Risk, The Econometric Society, Vol. 47, No. 2

33. Kennedy, S., 2008. The future of consumer policy: Should we regulate to protect homo economicus? Competition and Consumer Policy Division, Australian Treasury

34. Klingberg, T., 2009. The Overflowing Brain: Information Overload and the Limits of Working Memory, Oxford University Press

35. Lakerbaia, T., 2015. European Standard for Informed Consumer, Journal of Law N1, Tbilisi State University Publishing. (in Georgian)

36. Lakerbaia, T., Zaalishvili, V., Zoidze, T., 2018. Consumer Law, IBSU Publishing. (in Georgian) 
37. Law of Georgia on Product Safety and Free Movement Code, as of October 2021

38. Lee, B.K., and Lee, W.N., 2004, The Effect of Information Overload on Consumer Choice Quality in an On-Line Environment, Psychology \& Marketing, Vol.21

39. Micklitz, H. W., 2018. Legal Opinion of the Draft Law of Georgia on the Protection of Consumer Rights (As of March 2017), Comparative legal studies, \#6, GIZ

40. Micklitz, H.W., Reisch, L.A., Hagan, K. et al. 2011. An Introduction to the Special Issue on "Behavioural Economics, Consumer Policy, and Consumer Law", J Consum Policy 34, Springer, pp. 271-276

41. OECD Science, Technology and Industry Policy Papers, 2017. Use of Behavioural Insights in Consumer Policy, No. 36, OECD Publishing

42. Order of the President of the National Bank of Georgia №194/04 https://matsne. gov.ge/ka/document/view/4312325?publication=0 (in Georgian)

43. Order of the President of the National Bank of Georgia №32/04. https://matsne.gov. ge/ka/document/view/5117792?publication=0\#DOCUMENT:1 (in Georgian)

44. Order of the President of the National Bank of Georgia №37/04. https://matsne. gov.ge/ka/document/view/4081097?publication=8 Consolidated text: 14.07.2021 (in Georgian)

45. Paredes, T., 2003. Blinded by the Light: Information Overload and its Consequences for Securities Regulation, Washington University Law Quarterly, 81(2)

46. Regulatory Impact Assessment on the Draft Law of Georgia on Consumer Rights Protection, 2019. GIZ

47. Regulatory Impact Assessment on the Draft Law of Georgia on Consumer Rights Protection, 2016. http://www.moesd.gov.ge/uploads/publications/economy 450476725899caab552165.56302821.pdf [09.12.2021] (in Georgian)

48. Reich, N., Micklitz, H.W., 2014. "Economic Law, Consumer Interests and EU Integration" in Reich, N., et al (eds), European Consumer Law

49. Review of Australia's Consumer Policy Framework, Final Report, Australian Government Productivity Commission, 2008

50. Sibony, A.L., Helleringer, G., 2015. EU Consumer Protection and Behavioural Sciences: Revolution or Reform? Nudge and The Law, Hart Publishing

51. Simon, H.A., 1957. Rational Choice and the Structure of the Environment, Psychological Review, 63(2)

52. Sunstein, C., 2015. Choosing not to Choose: Understanding the Value of Choice, Oxford University Press

53. Tscherner, E.M., 2014. Can Behavioral Research Advance Mandatory Law, Information Duties, Standard Terms and Withdrawal Rights?, Austrian Law Journal, N1

54. Waselius and Wist, New temporary restrictions on interest rates and direct marketing of consumer loans. https://www.ww.fi/news/2020/04/new-temporary-restrictions-on-interest-rates-and-direct-marketing-of-consumer-loans/ [26.10.2021]

55. Wilhelmsson, T., Twigg-Flesner, C., 2006. Pre-contractual information duties in the acquis communautaire. European review of contract law: ERCL., 2(4) 


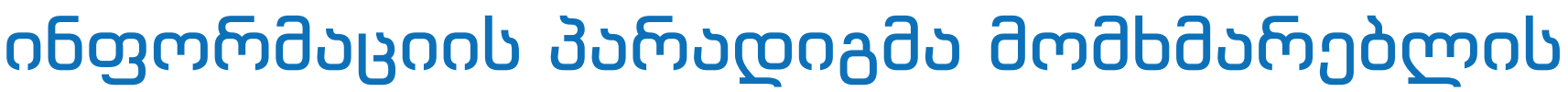

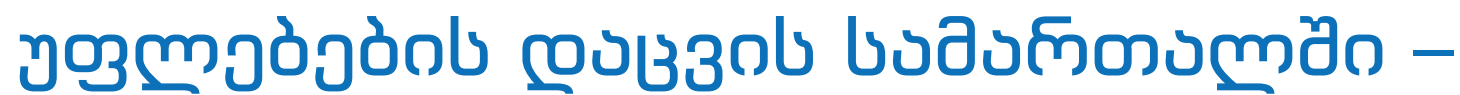

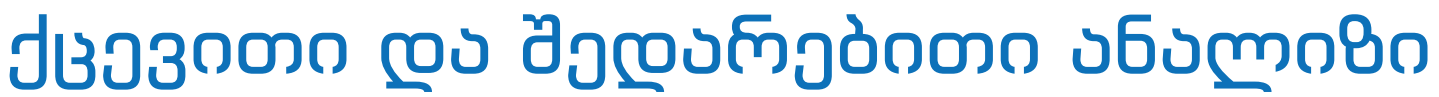

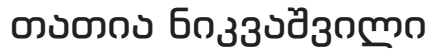

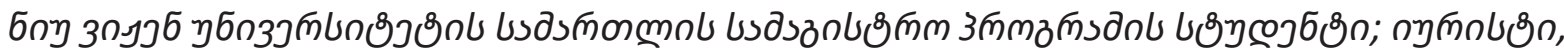

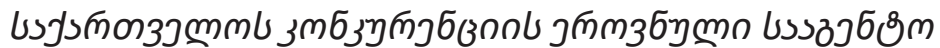

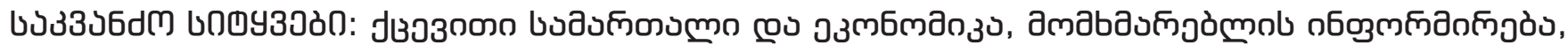

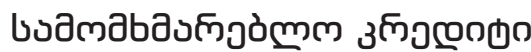

\section{ฆองל3งณn}

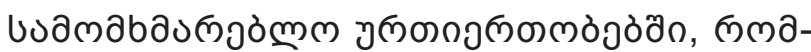

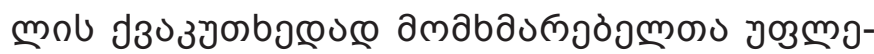

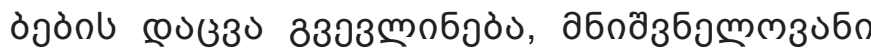

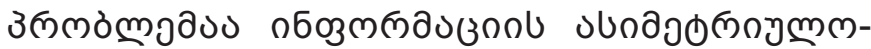

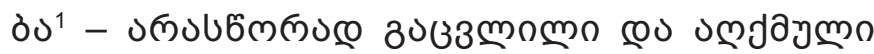

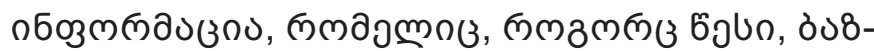

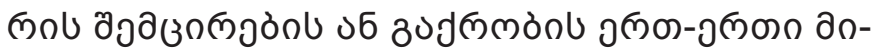

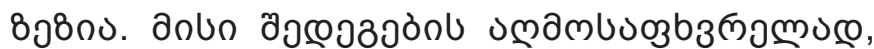

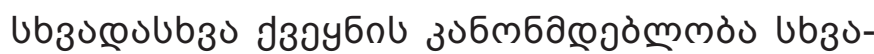

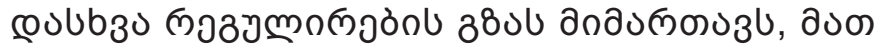

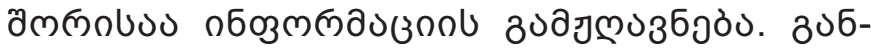

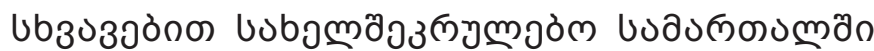

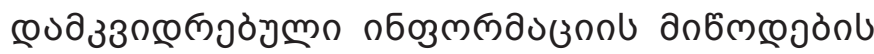

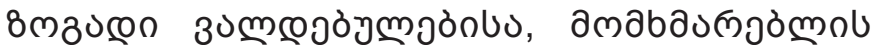

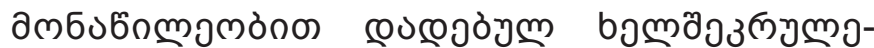

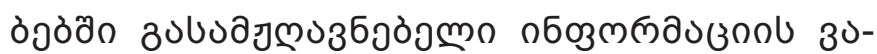

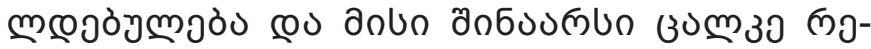

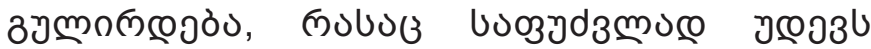

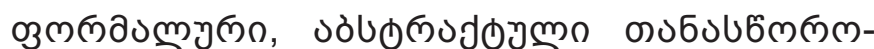

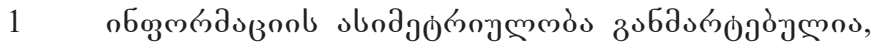

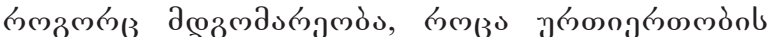
9 ऊо-

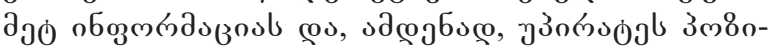

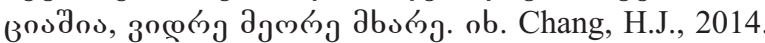
Economics: The User's Guide, London, Penguin, p. 391.

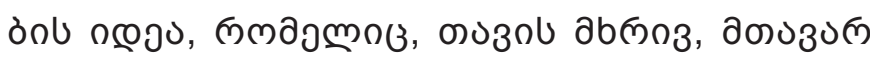

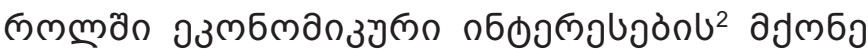

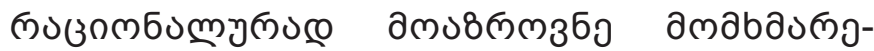

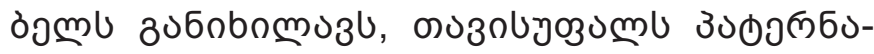

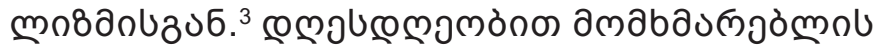

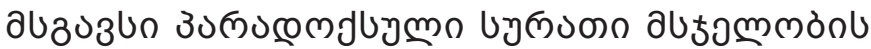

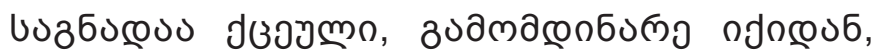

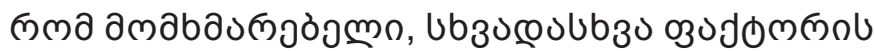

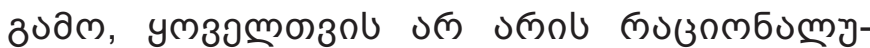

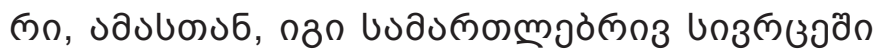

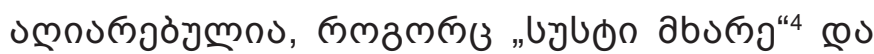

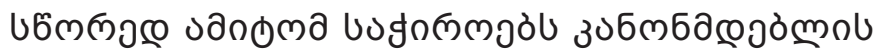

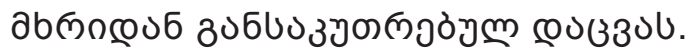

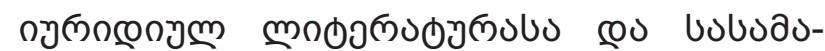

2 do3., ob. Case C-59/12 BKK Mobil Oil Korperschaft des offentlichen Rechts v Zentrale zur Bekampfung unlauteren Wettbewerbs eV [2013]

3 Dani, M., 2011. Assembling The Fractured European

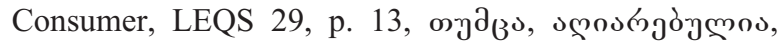

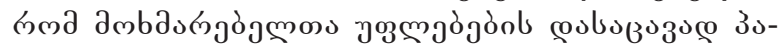

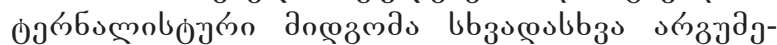

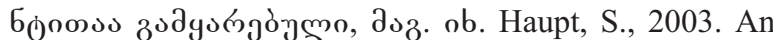
Economic Analysis of Consumer Protection in Contract Law, German Law Journal, 4(11), p. 1161.

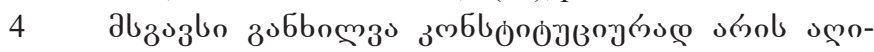

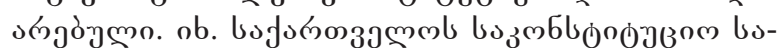

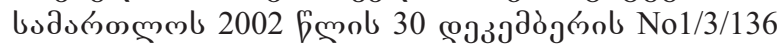

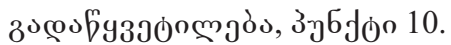




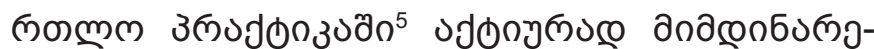

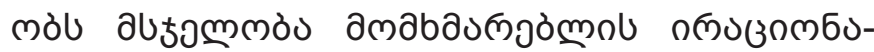

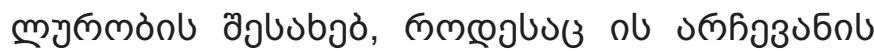

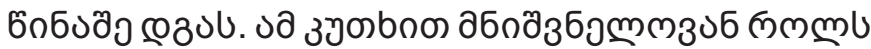

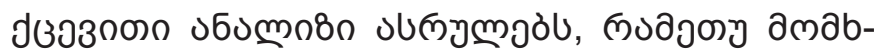

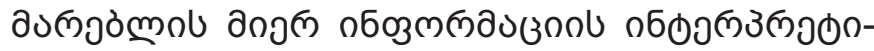

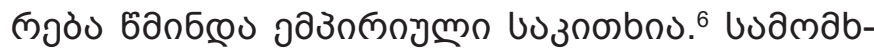

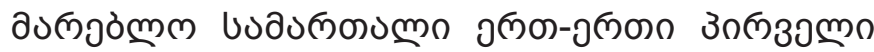

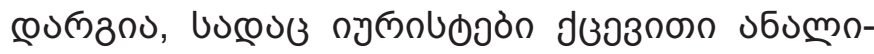

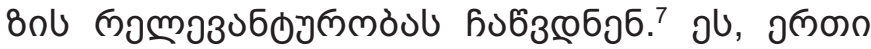

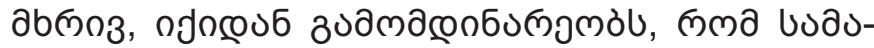

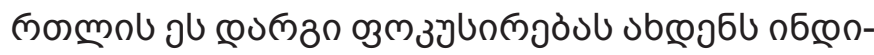

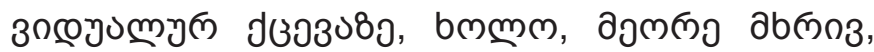

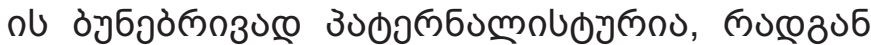

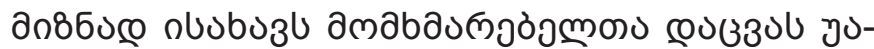

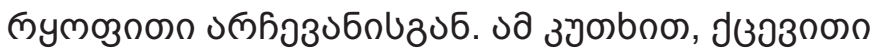

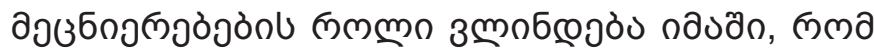

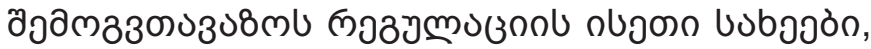

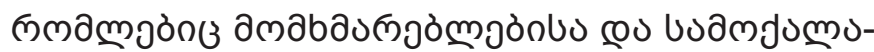

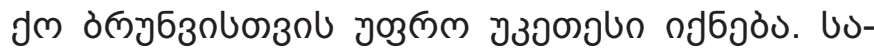

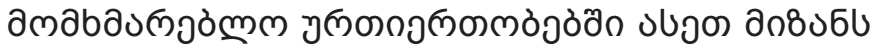

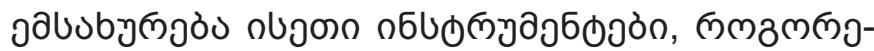

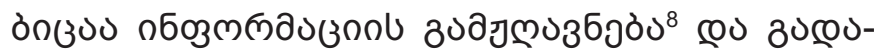

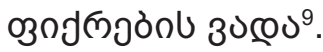

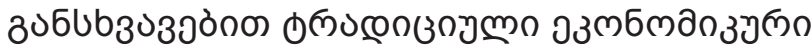

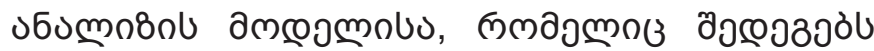

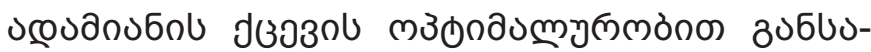

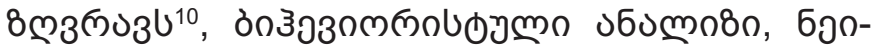

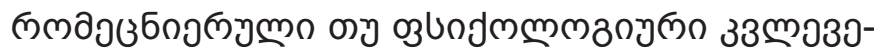

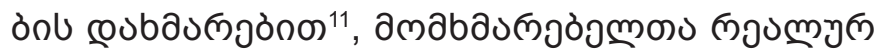

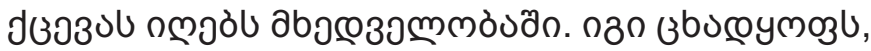

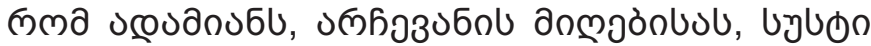

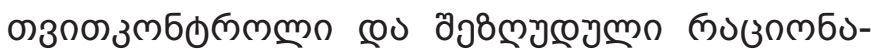

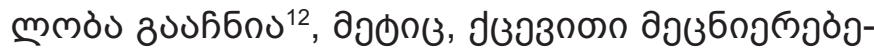

5

də3., ob. Case C-382/87, Buet v Ministère Public [1989] ECR 1235.

6 Beales, J.H., 2008. Consumer Protection and Behavioral Economics: To BE or Not to BE? Competition Policy International, p. 165.

7 Sibony, A.L., Helleringer, G., 2015. EU Consumer Protection and Behavioural Sciences: Revolution or Reform? Nudge and The Law, Hart Publishing, p. 209.

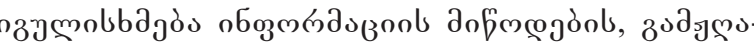

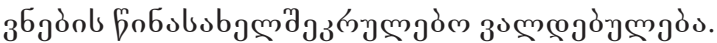

9 э. $[$. „cooling-off period”.

10 Australian Government Productivity Commission, 2007. Review of Australia's Consumer Policy Framework, Draft Report, p. 319.

11 ob. Calabresi, G., 2016. The Future of Law and Economics, Yale University Press, p. 5

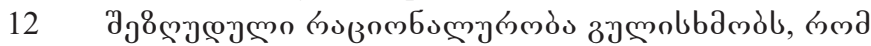

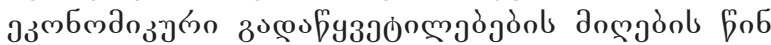

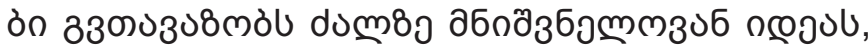

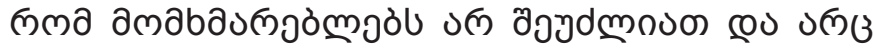

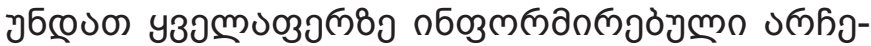

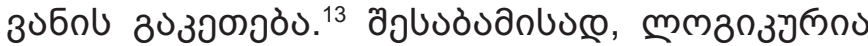

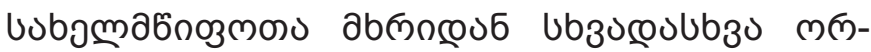

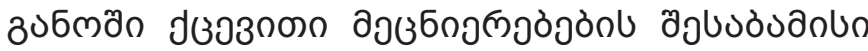

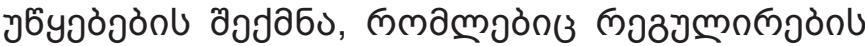

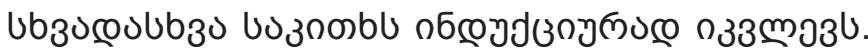

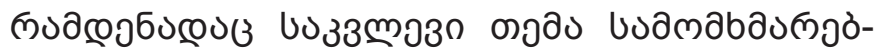

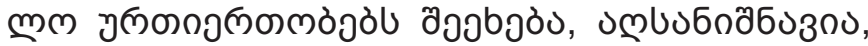

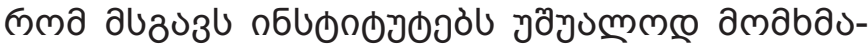

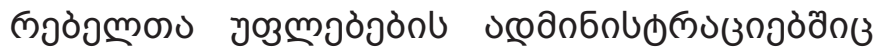

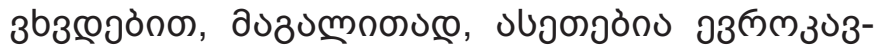

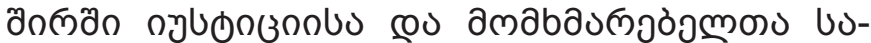

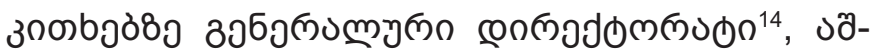

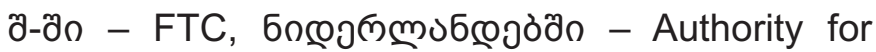

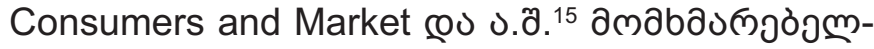

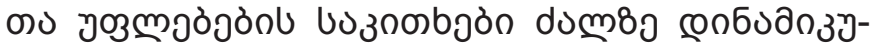

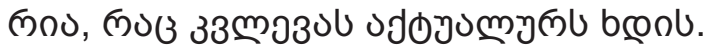

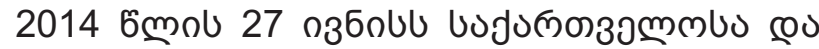

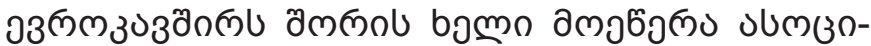

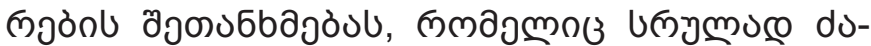

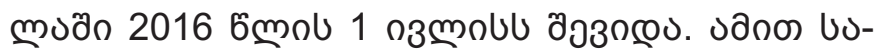

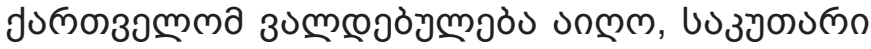

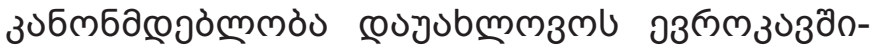

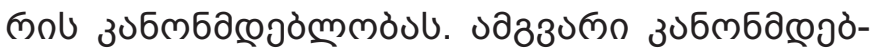

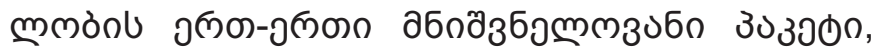

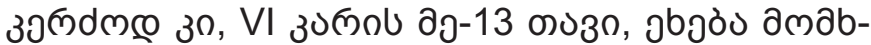

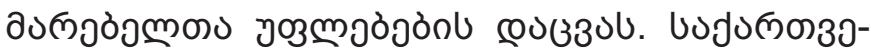

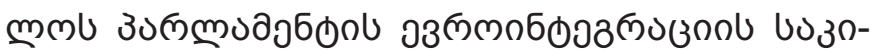

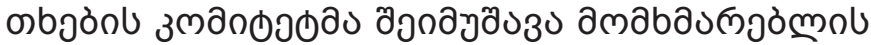

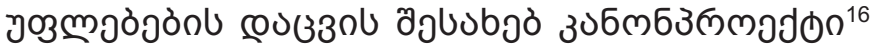

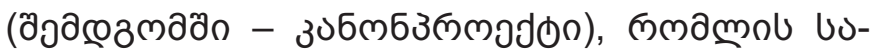

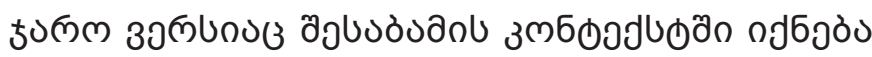

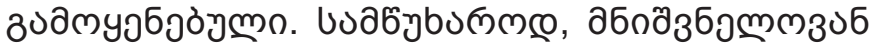

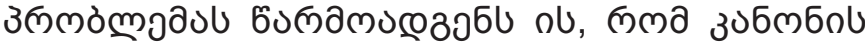

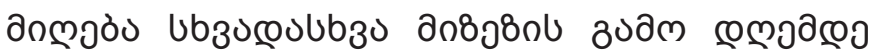

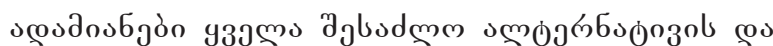

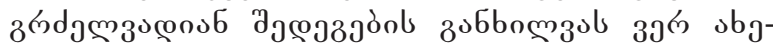
rbyò 5. ob. Simon H.A., 1957, Rational Choice and the Structure of the Environment, in Models of man: social and rational; New York, Wiley, p. 198.

13 Sunstein, C., 2015. Choosing not to Choose: Understanding the Value of Choice, Oxford University Press.

14 DG Justice and Consumers.

15 ob. OECD Science, Technology and Industry Policy Papers, 2017. Use of Behavioural Insights in Consumer Policy, No. 36, OECD Publishing, Paris, p. 10.

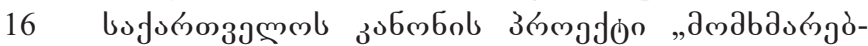

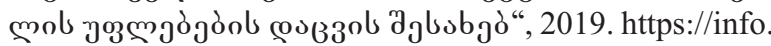
parliament.ge/file/1/BillReviewContent/224285? 


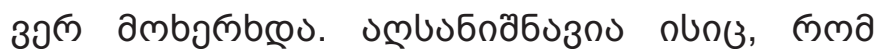

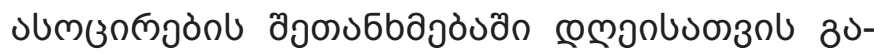

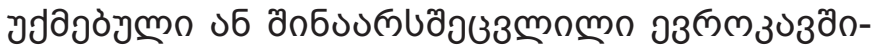

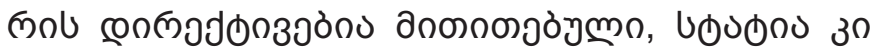

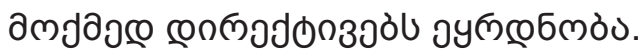

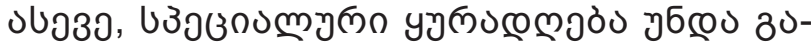

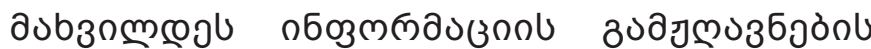

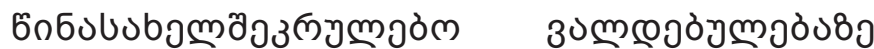

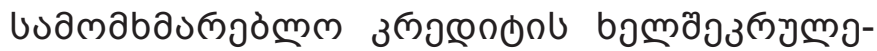

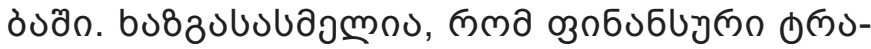

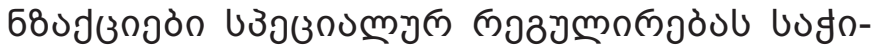

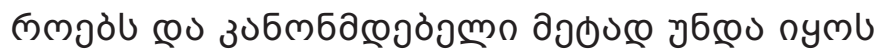

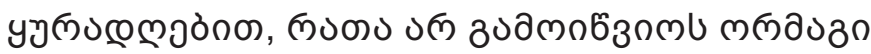

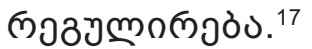

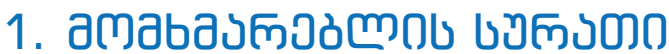

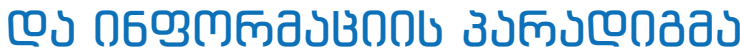

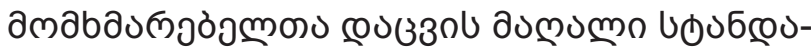

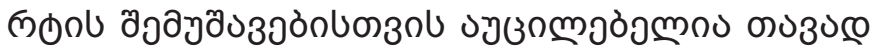

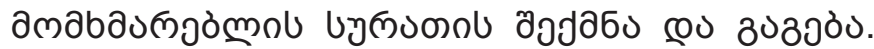

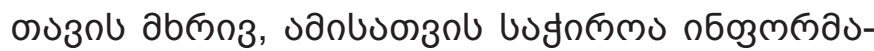

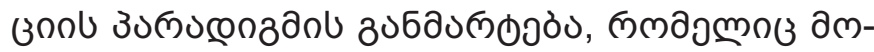

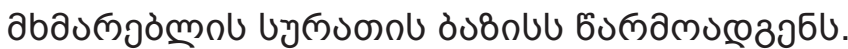

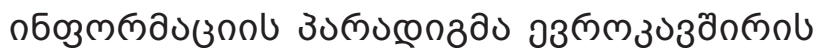

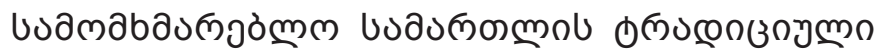

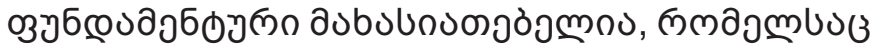

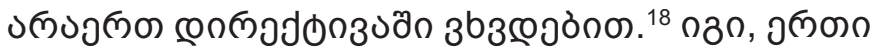

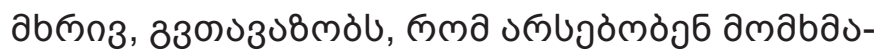

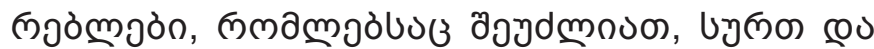

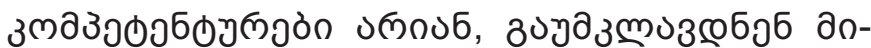

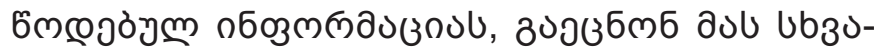

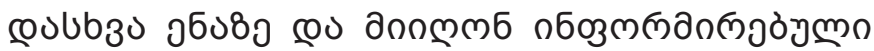

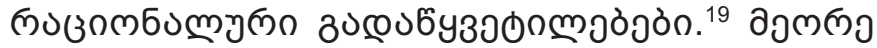

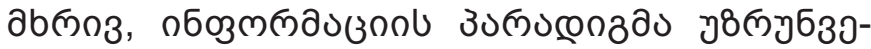

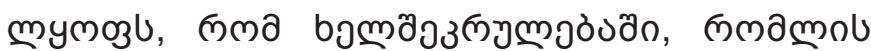

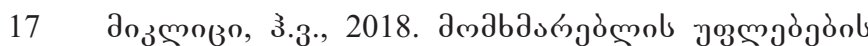

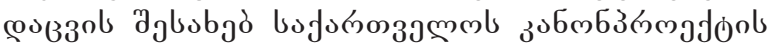

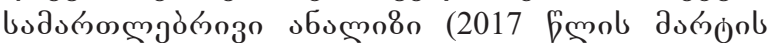

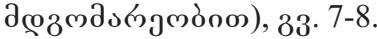

18 Reich, N., Micklitz, H.W., 2014. "Economic Law, Consumer Interests and EU Integration" in Reich, N., et al (eds), European Consumer Law Cambridge, p. 21. дっ-

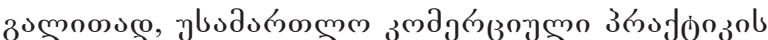

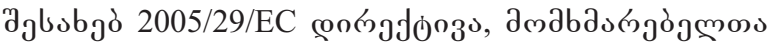

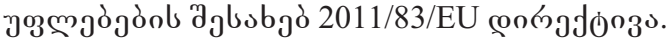

19 Micklitz, H.W., Reisch, L.A., Hagan, K., 2011. An Introduction to the Special Issue on "Behavioural Economics, Consumer Policy, and Consumer Law", Springer, p. 271.

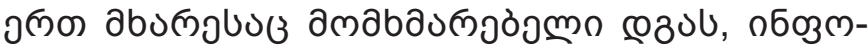

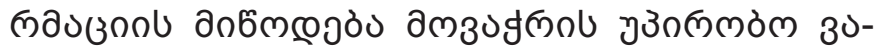

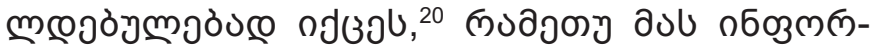

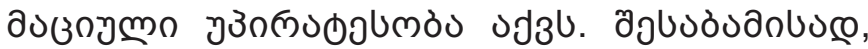

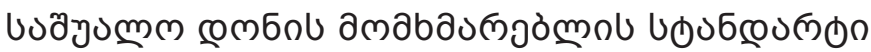

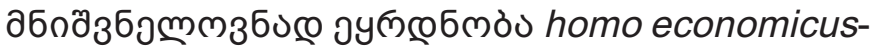

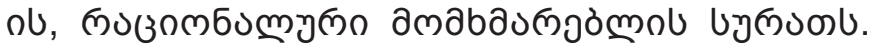

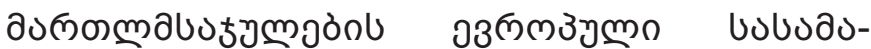

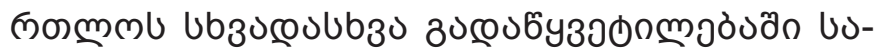

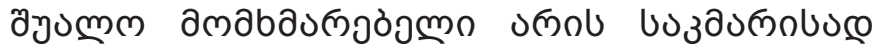

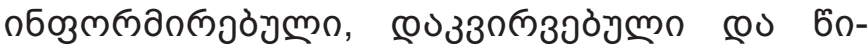

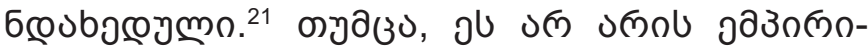

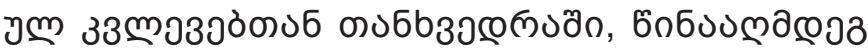

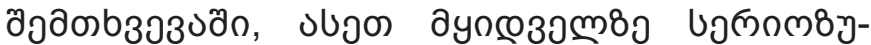

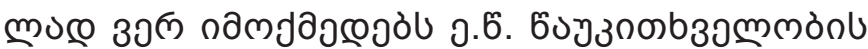

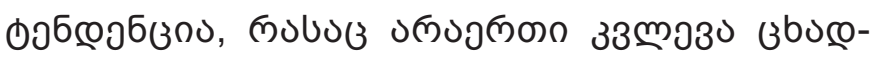

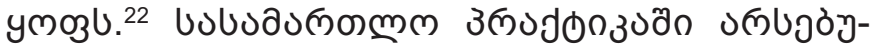

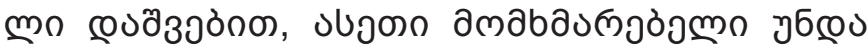

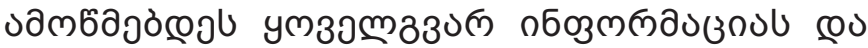

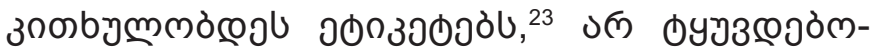

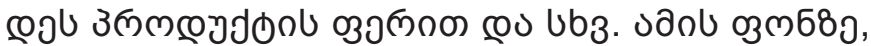

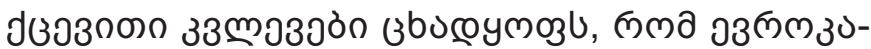

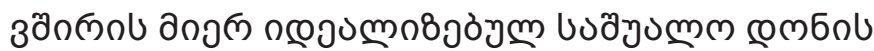

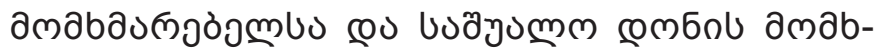

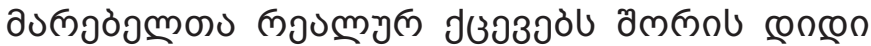
30бub30300े00. ${ }^{24}$

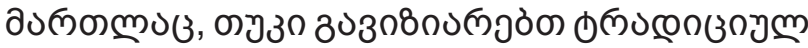

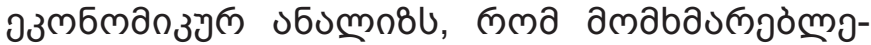

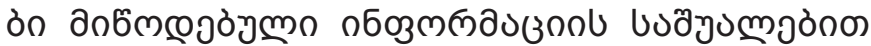

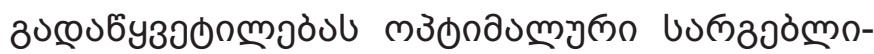

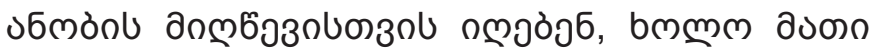

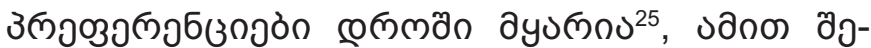

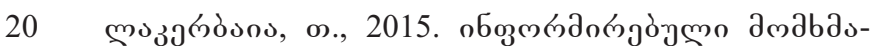

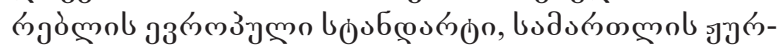
Бзмло 1, 33.147.

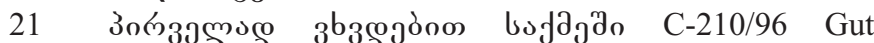

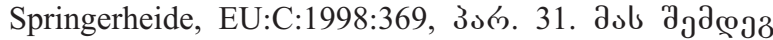

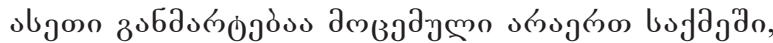
dəs., Canal Digital Danmark, C 611/14, EU:C:2016:800, उっю́. 39.

22 Aryes, I., Schwartz, A., 2014. The No-Reading Problem in Consumer Contract Law, Stanford Law Review, Vol. 66,

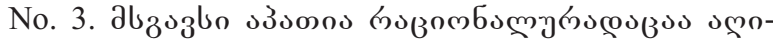
ง'rjòymo - ob. Ben-Shahar, O., 2009. The Myth of the "Opportunity to Read" in Contract Law, European Review of Contract Law, p. 5.

23 дı2., Case C-51/94 Commission v Germany,

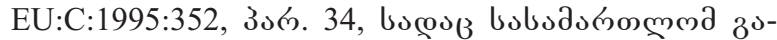

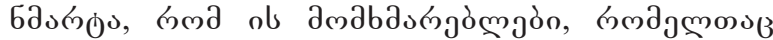

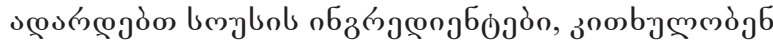

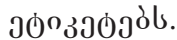

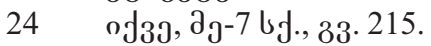

25 Kennedy, S., 2008. The future of consumer policy: Should 


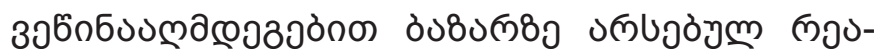

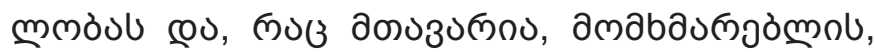

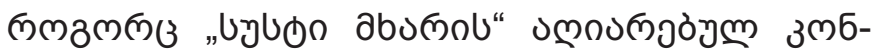

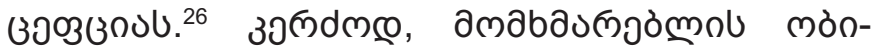

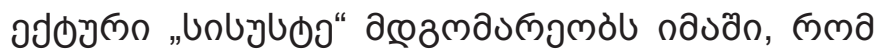

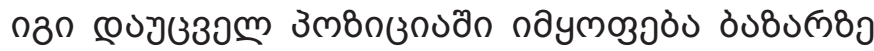

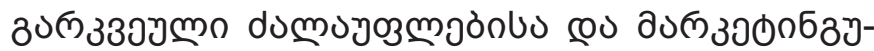

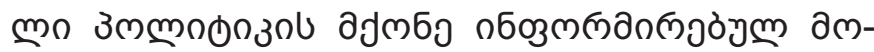

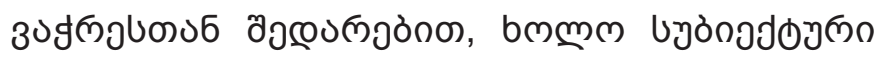

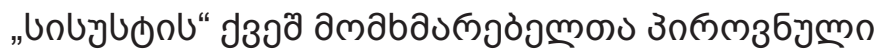

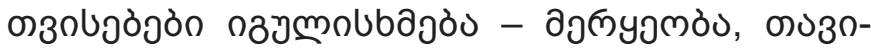

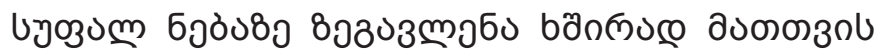

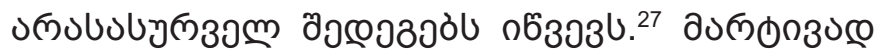

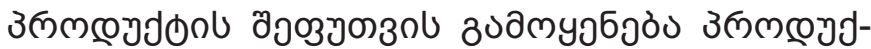

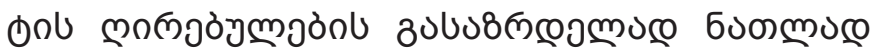

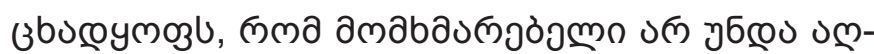

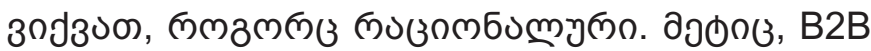

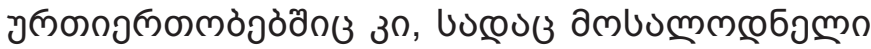

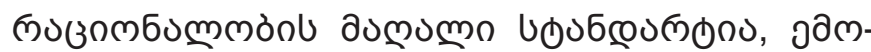

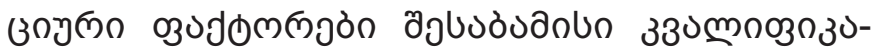

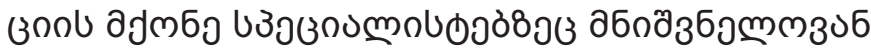

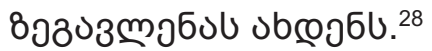

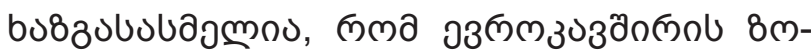

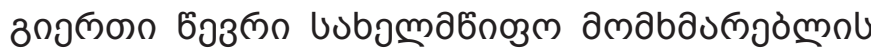

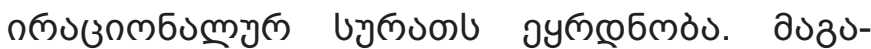

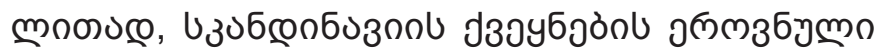

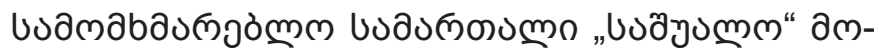

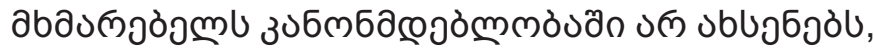

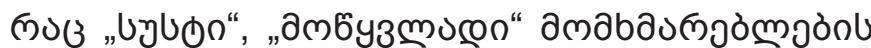

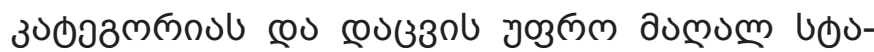

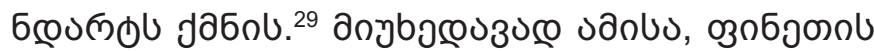

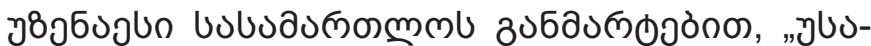

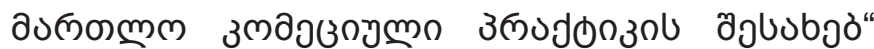

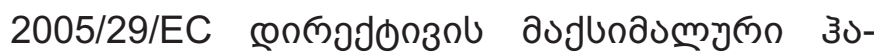

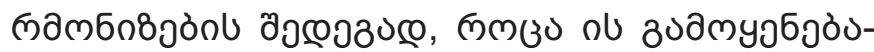

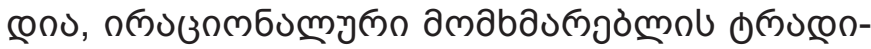

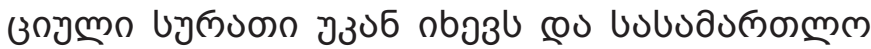

we regulate to protect homo economicus? Competition and Consumer Policy Division, Australian Treasury, p. 10. ob. $\mathrm{d} g-4 \mathrm{~b} f$.

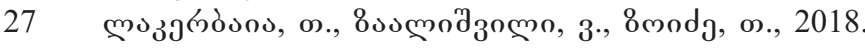

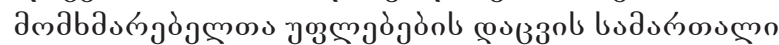

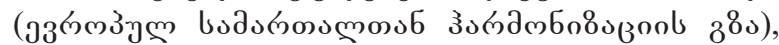
oòby, 33.49.

Hague, P., A Guide to B2B Marketing And How it Differs From Consumer Marketing, https://www.b2binternational. com/publications/b2b-marketing/ [оेммм бзгодљ: 26.10.2021].

29 Hyvöven, S., 2019. Information Obligations and Disinformation of Consumers: Finnish Law Report, Springer, p. 411

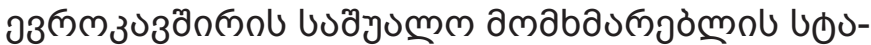

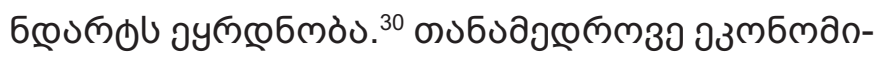

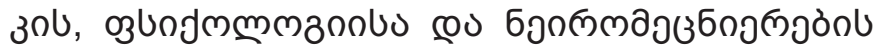

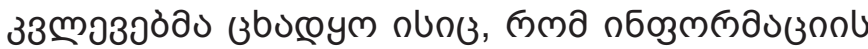

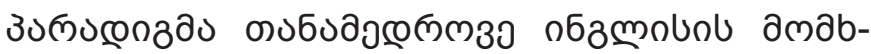

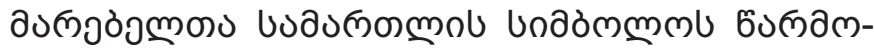

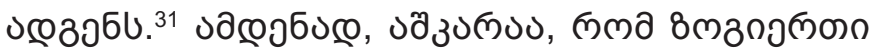

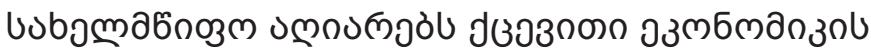

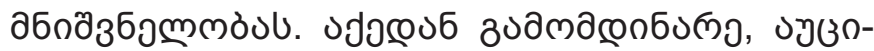

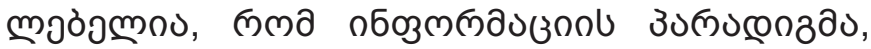

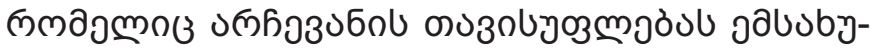

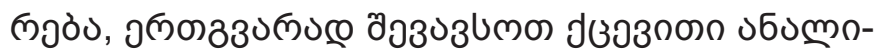

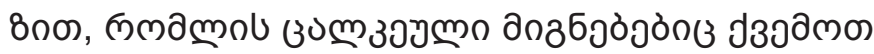

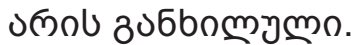

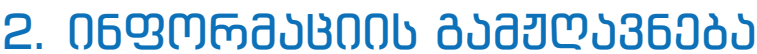

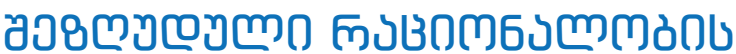

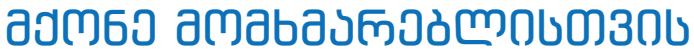

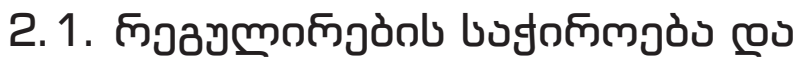

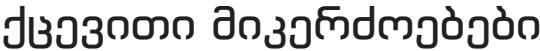

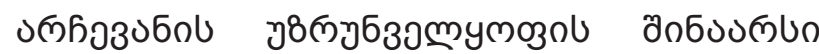

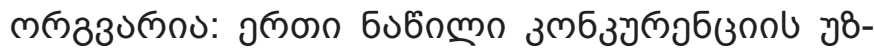

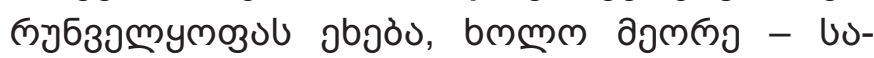

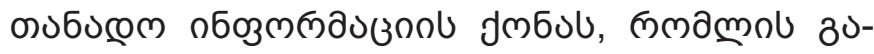

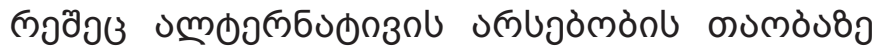

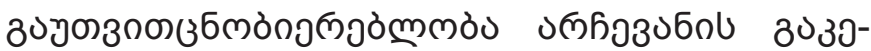

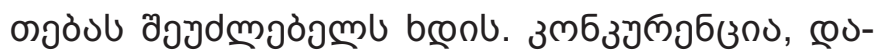

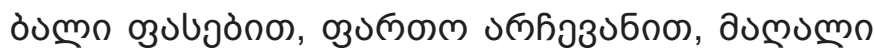

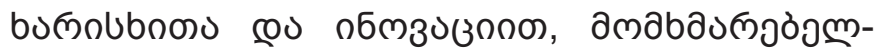

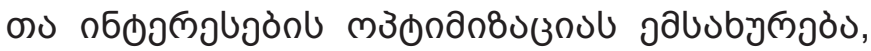

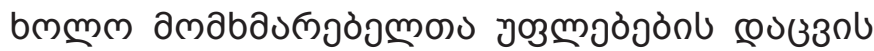

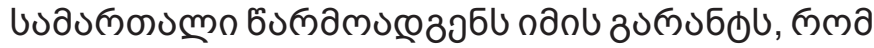

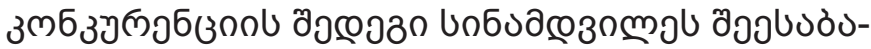

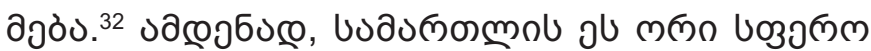

30 Finnish Supreme Court Decision KKO 2017:83, bəøо (3

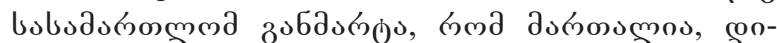

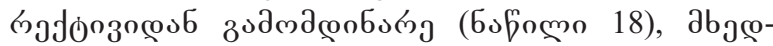

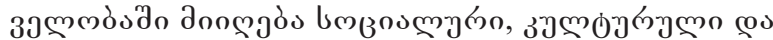

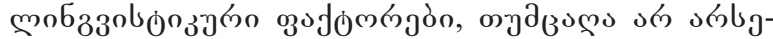

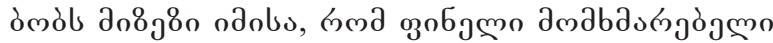

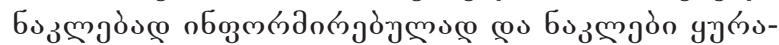

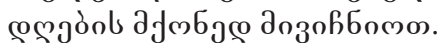

31 Bush, C., 2016. The Future of Pre-Contractual information Duties: From Behavioural Insights to Big Data, Research Handbook on EU Consumer and Contract Law, p. 221.

32 De Pree, J., 2019. Trends: anti-trust, consumer and privacy regulation increasingly converge, https://www.debrauw. com/legalarticles/trends-anti-trust-consumer-and-privacyregulation-increasingly-converge/ [оेммм бзюмдљ: 


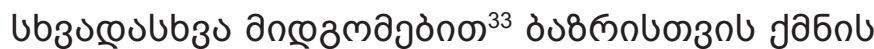

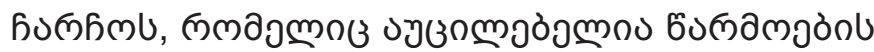

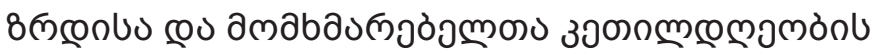
aоbงm6030ณ. ${ }^{34}$

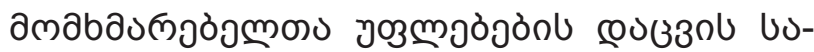

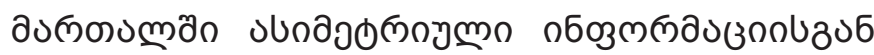

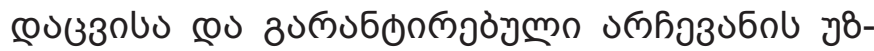

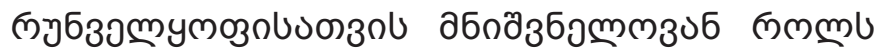

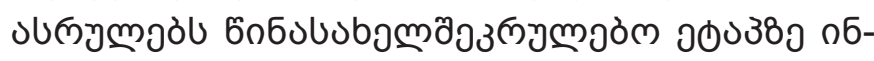

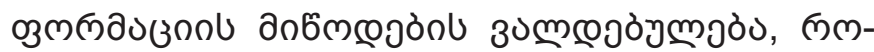

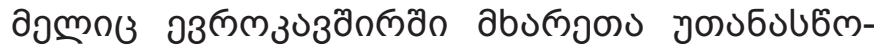

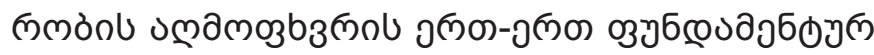

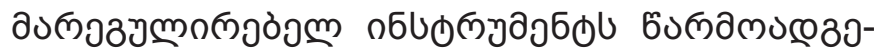

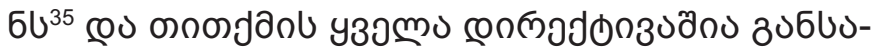

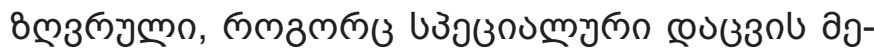

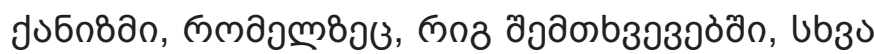

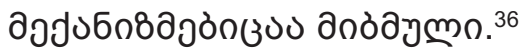

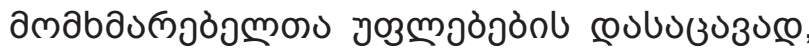

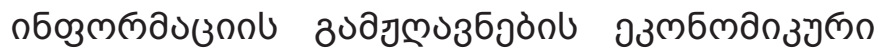

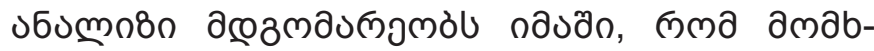

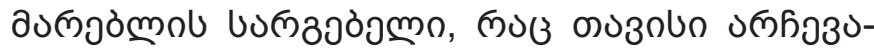

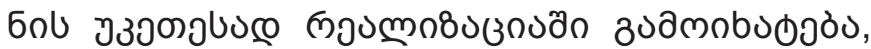

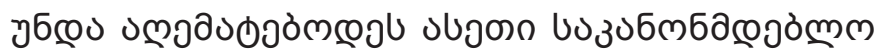

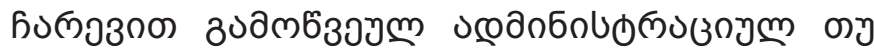

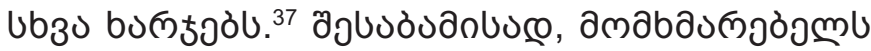

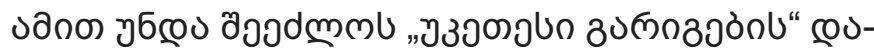

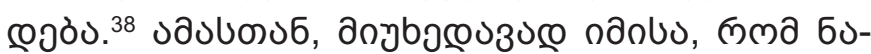

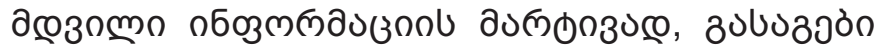

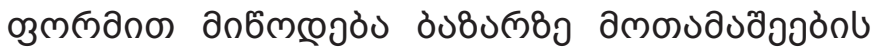

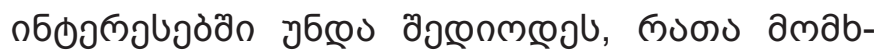

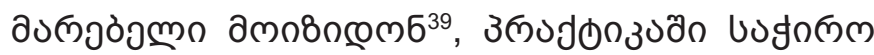

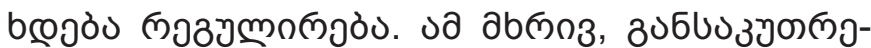

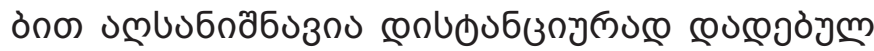

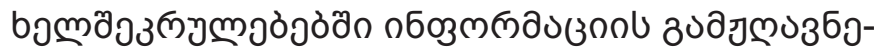

26.10.2021].
Huffman, M., 2010. Bridging the Divide? Theories for Integrating Competition law and Consumer Protection, European Competition Journal, April, p. 7 .

of39.

Wilhelmsson, T., \& Twigg-Flesner, C., 2006. Pre-contractual information duties in the acquis communautaire. European review of contract law: ERCL., 2(4), pp. 441-470.

of39, 26-g bf. 124.

Haupt, S., 2003, An Economic Analysis of Consumer Protection in Contract Law, German Law Journal, 4(11), p. 1142.

Grynbaum, L., 2010. Pre-contractual Information Duties the foreseeable failure of full harmonisation, Prospectives of European Consumer Law, Towards a Directive on Consumer Rights and Beyond, Schulte-Nölke, H., Tichŷ, L., (eds.), Sellier, p. 7.

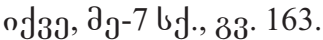

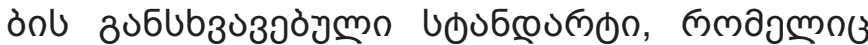

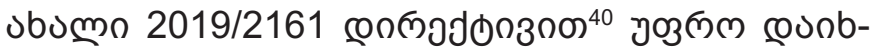

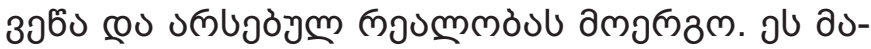

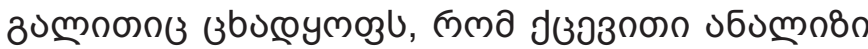

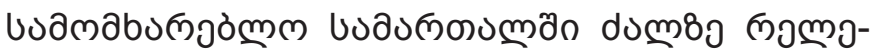
उ०бळगलоง.

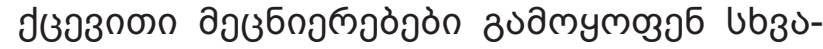

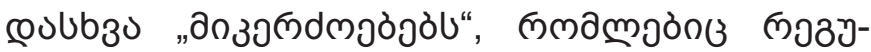

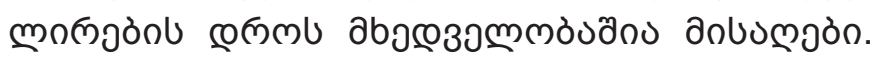

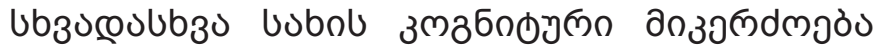

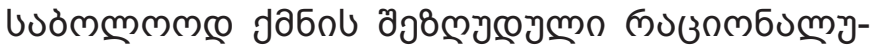

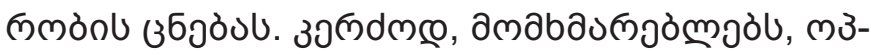

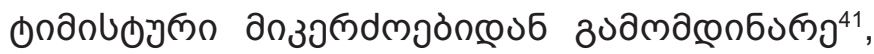

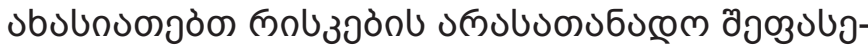

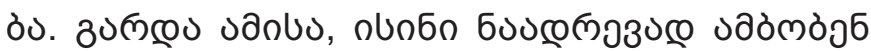

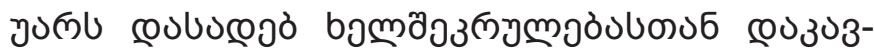

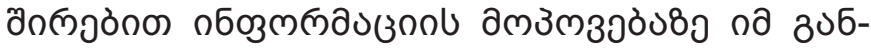

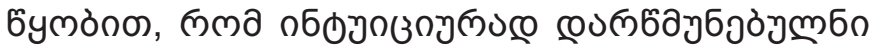

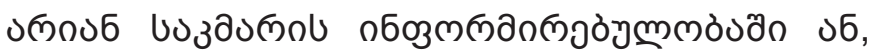

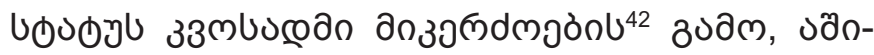

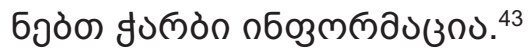

\section{2. "bo60ommolouav6

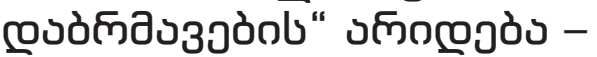

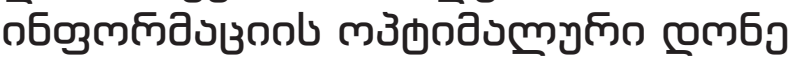

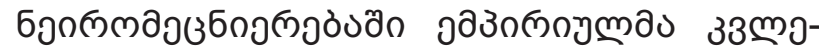

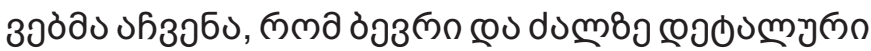

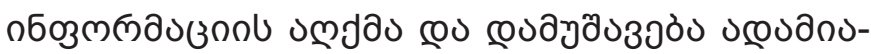

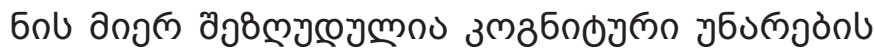

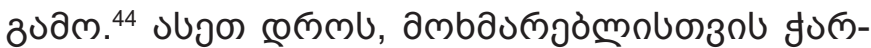

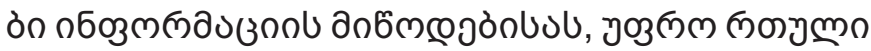

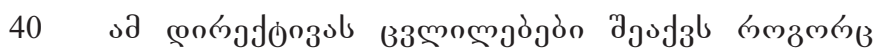

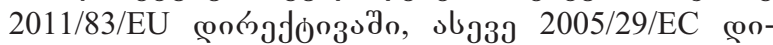

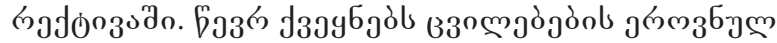

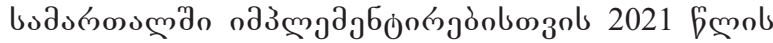

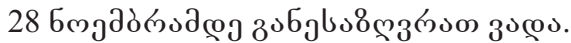

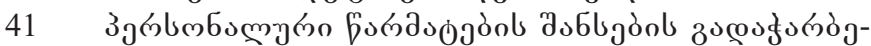

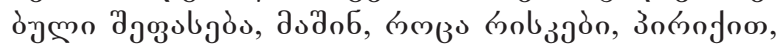

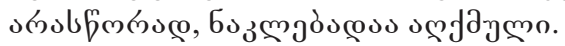

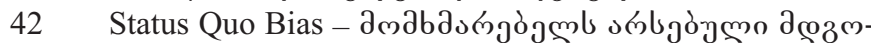

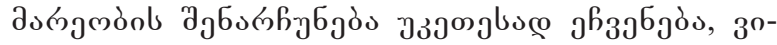

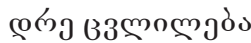

43 Dean, M., Kibris, O., Masatlioglu, Y., 2017. Limited attention and status quo bias. Journal of Economic Theory, pp. 93-127.

44 Klingberg, T., 2009. The Overflowing Brain: Information Overload and the Limits of Working Memory, Oxford

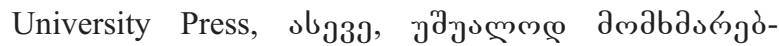
məò $\mathrm{j}$ - Lee, B.K., and Lee, W.N., 2004, The Effect of Information Overload on Consumer Choice Quality in an On-Line Environment, Psychology \& Marketing, p. 159. 


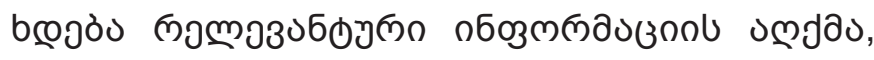

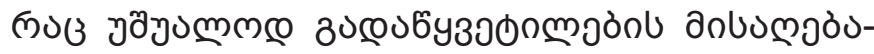

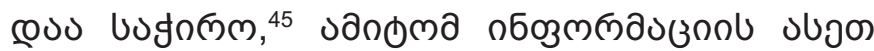

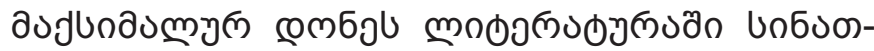

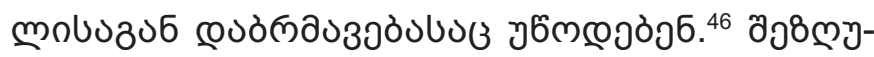

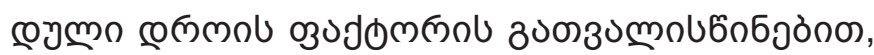

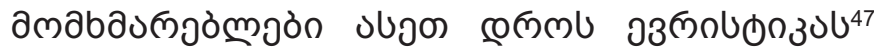

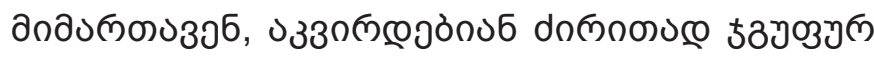

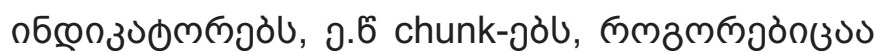

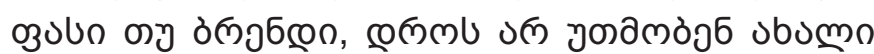

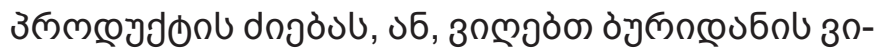

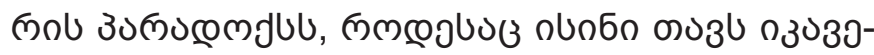

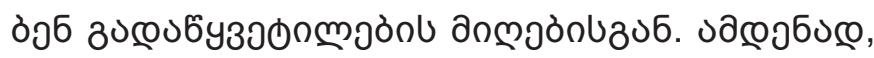

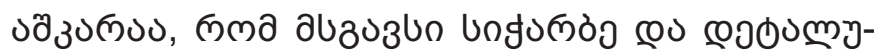

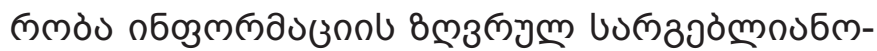

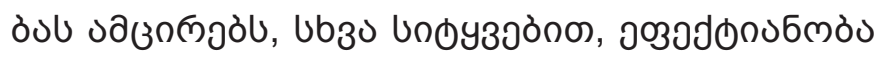

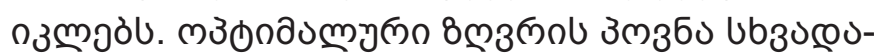

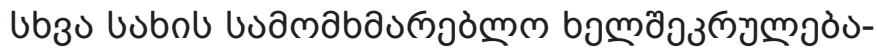

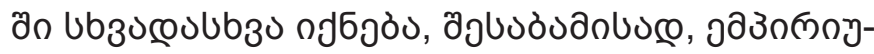

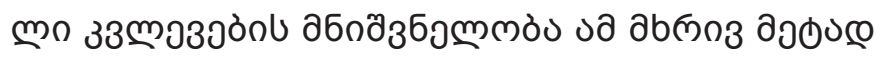

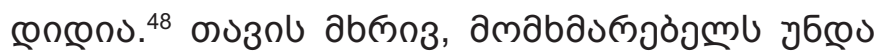

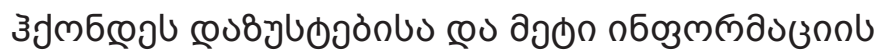

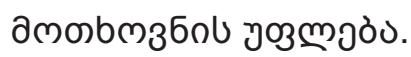

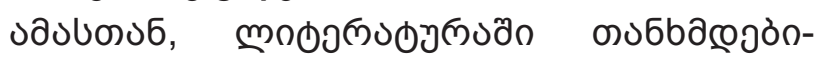

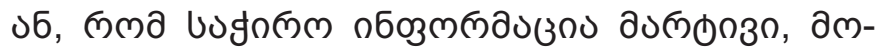

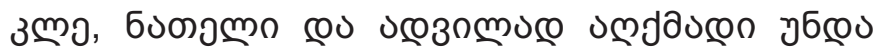

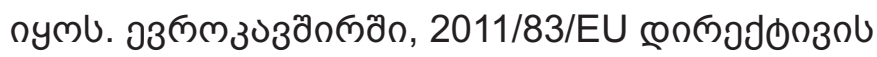

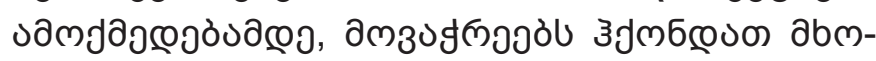

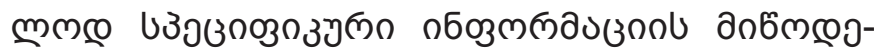

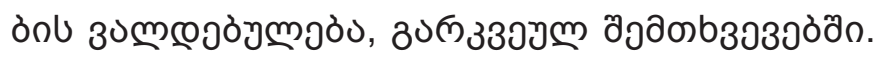

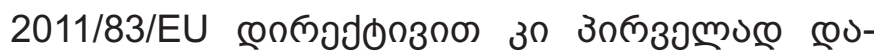

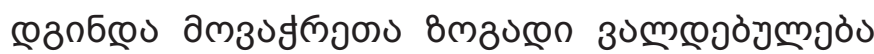

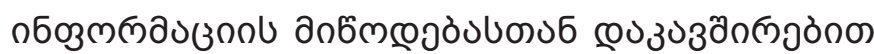

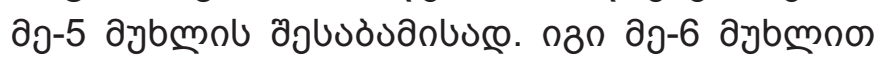

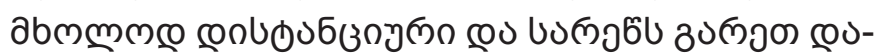

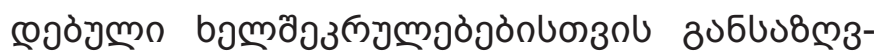

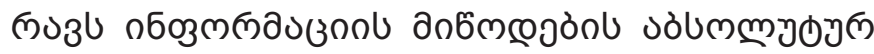

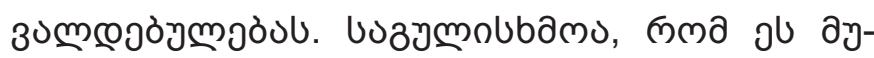

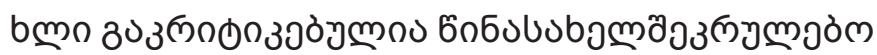

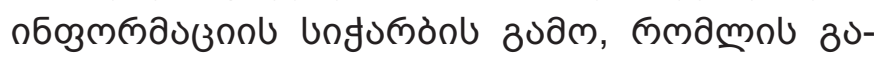

Djurovic, M., 2016. The Duty of Information. European Law on Unfair Commercial Practices and Contract Law, Oxford: Hart Publishing, p. 139.

Paredes, T., 2003. Blinded by the Light: Information Overload and its Consequences for Securities Regulation, Washington University Law Quarterly, 81(2), p. 417.

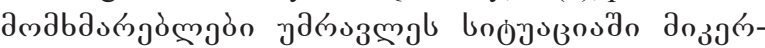

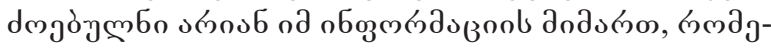

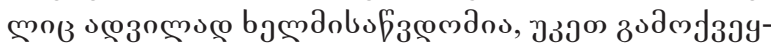

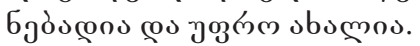

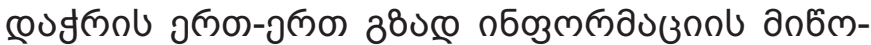

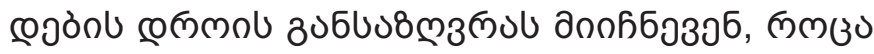

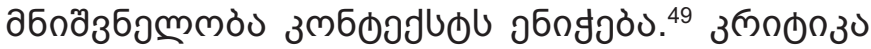

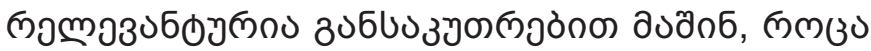

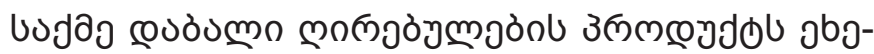

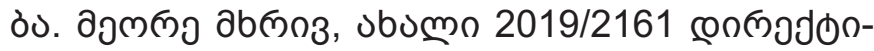

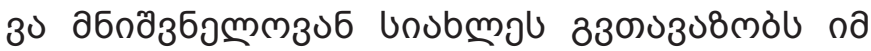

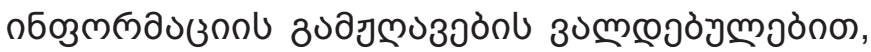

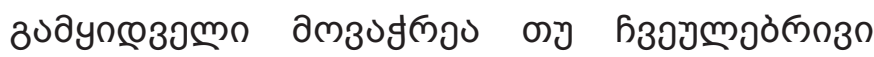

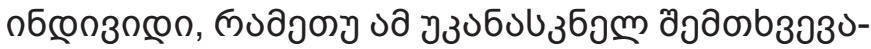

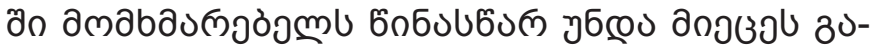

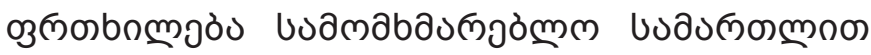

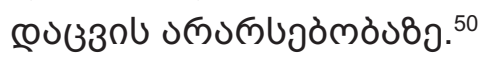

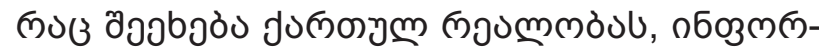

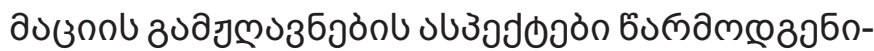

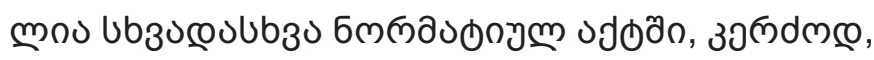

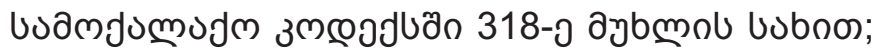

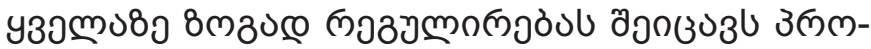

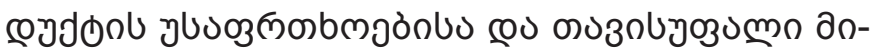

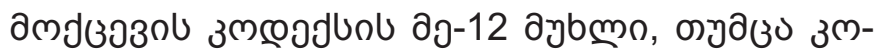

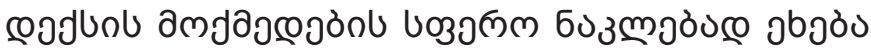

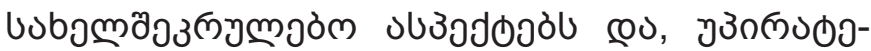

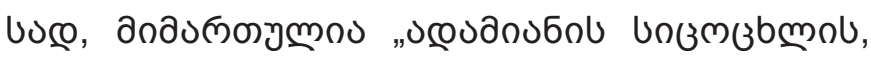

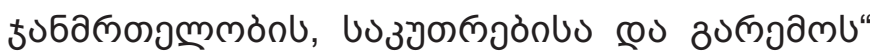

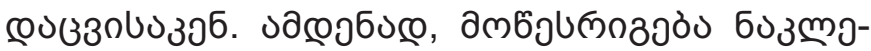

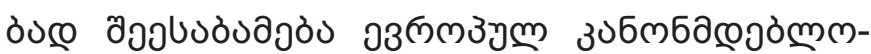

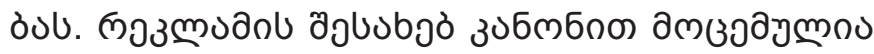

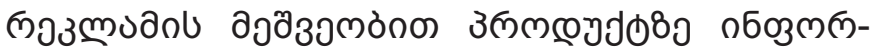

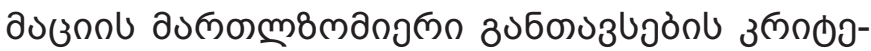

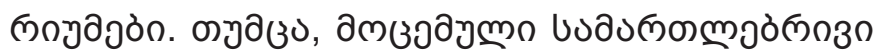

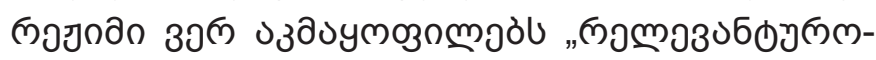

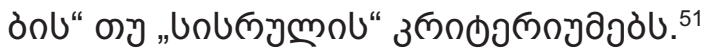

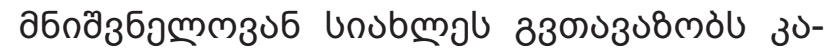

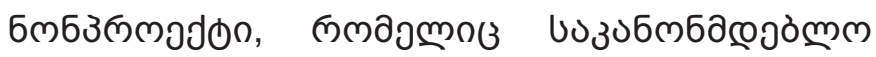

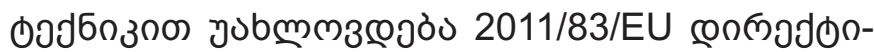

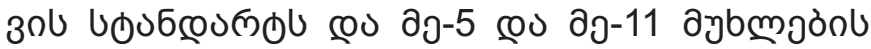

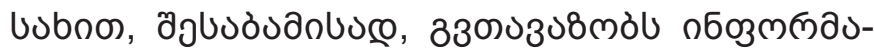

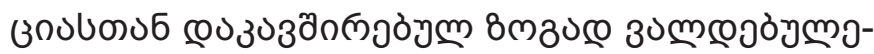

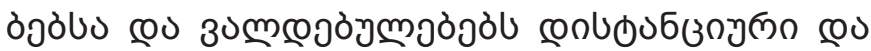

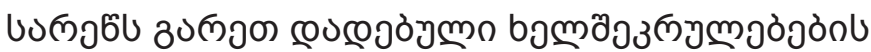

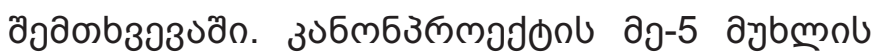

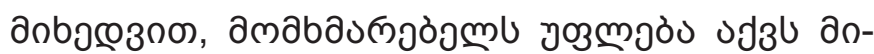

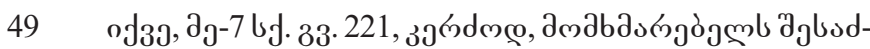

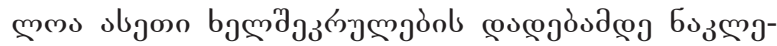

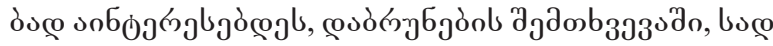

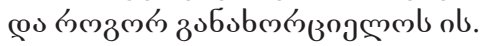

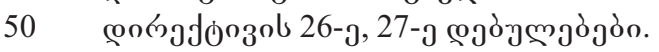

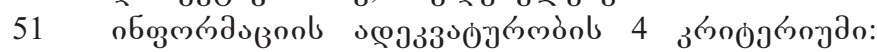

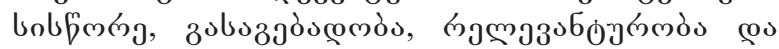

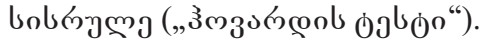




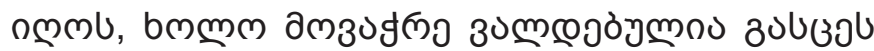

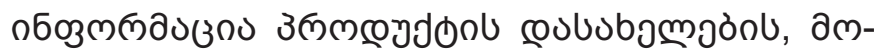

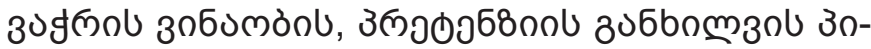

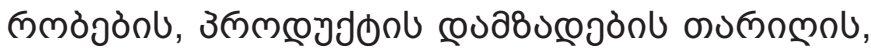

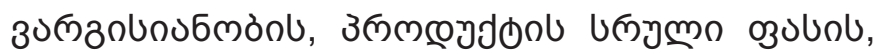

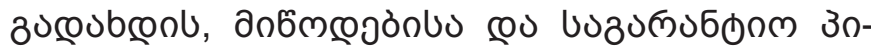

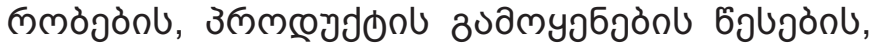

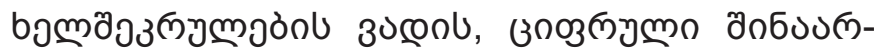

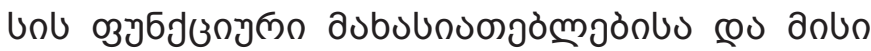

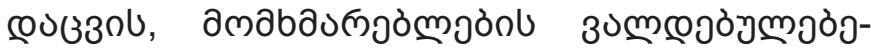

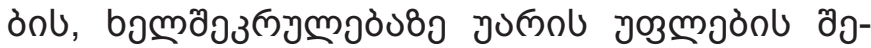

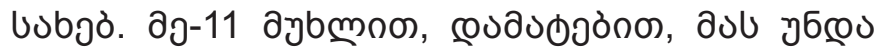

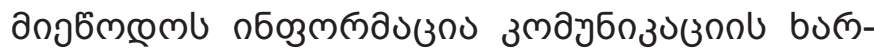

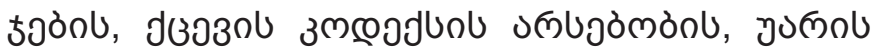

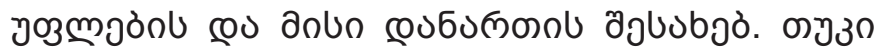

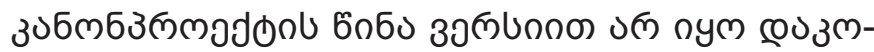

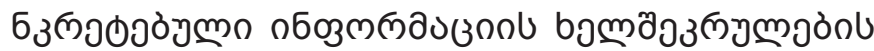

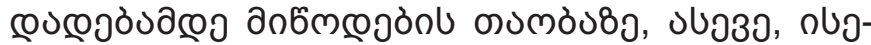

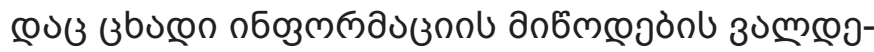

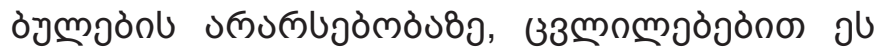

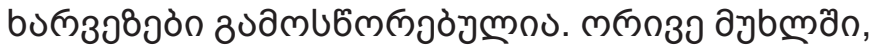

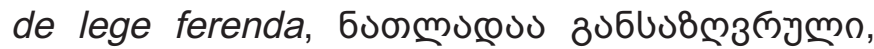

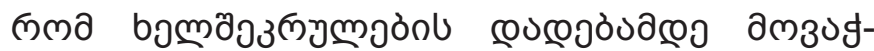

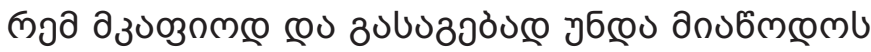

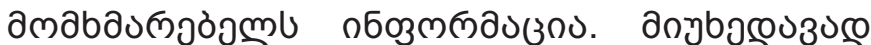

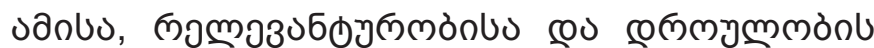

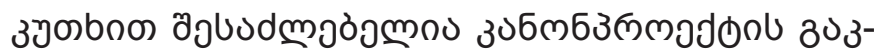

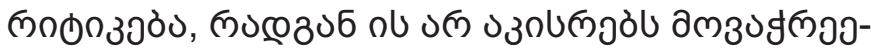

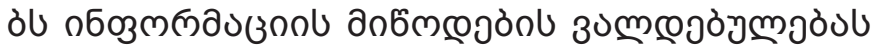

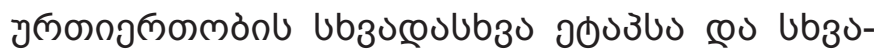

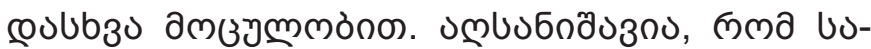

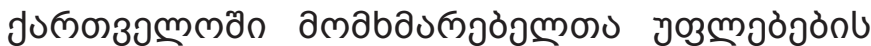

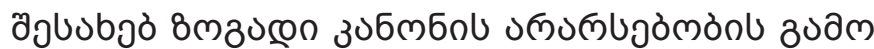

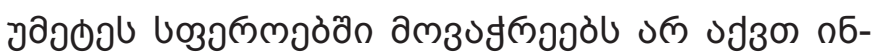

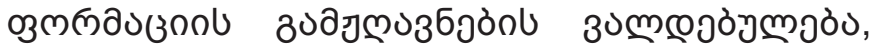

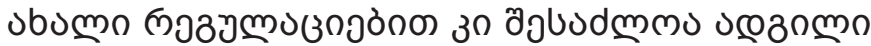

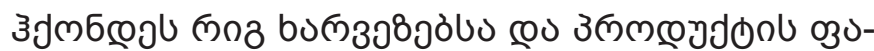

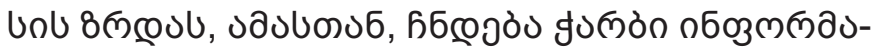

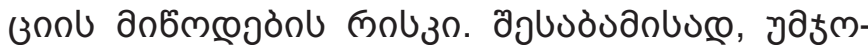

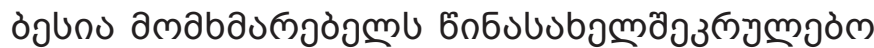

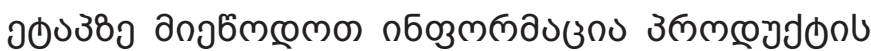

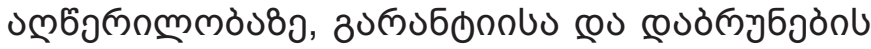

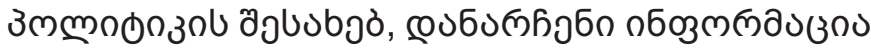

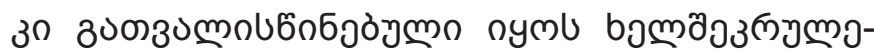

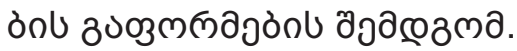

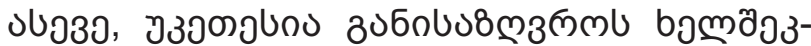

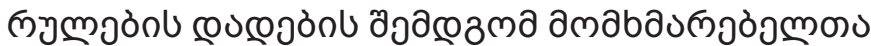

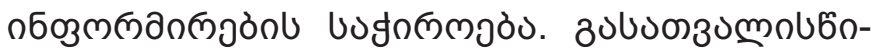

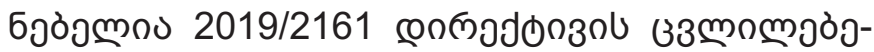

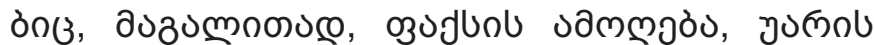

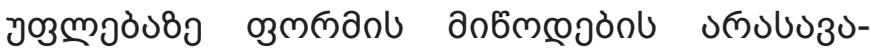

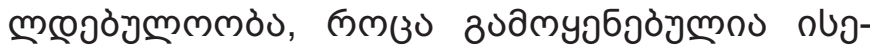

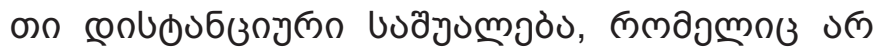

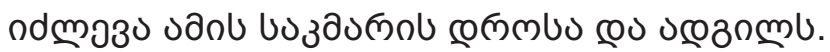

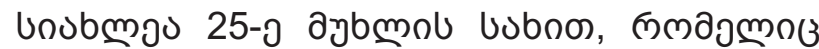

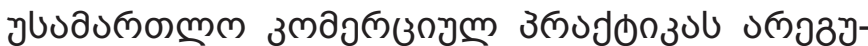

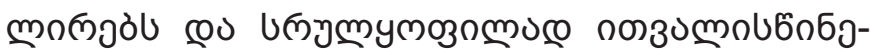

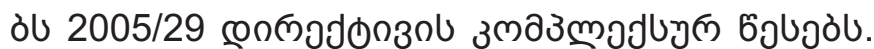

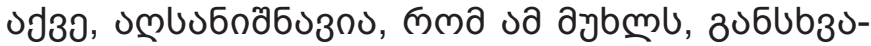

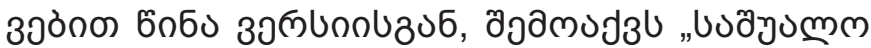

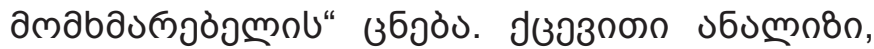

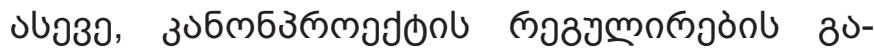

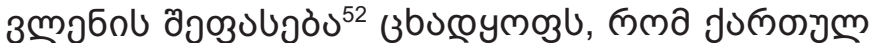

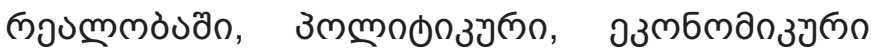

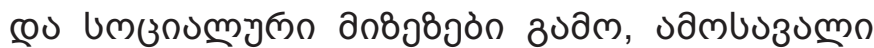

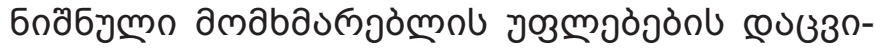

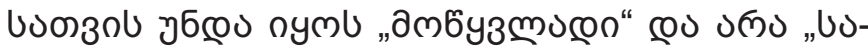

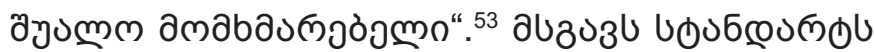

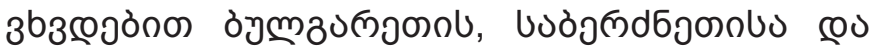

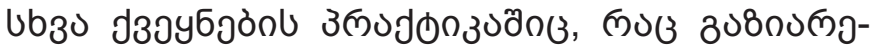

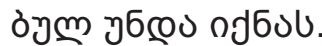

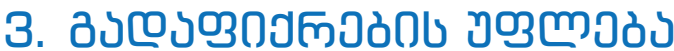

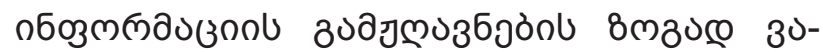

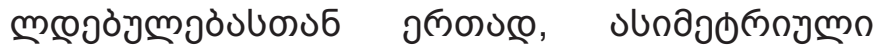

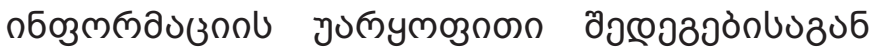

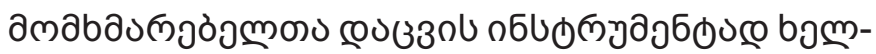

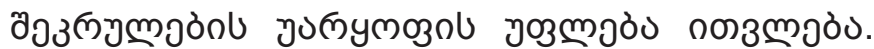

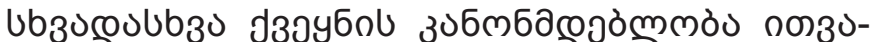

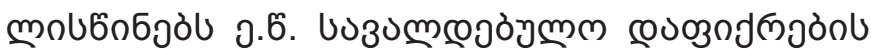

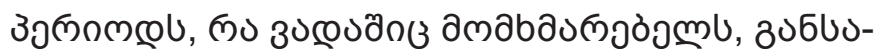

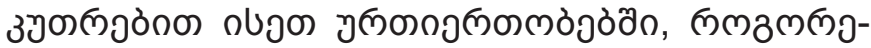

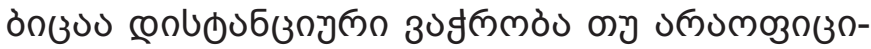

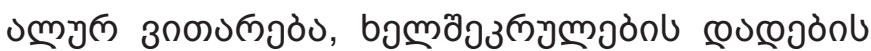

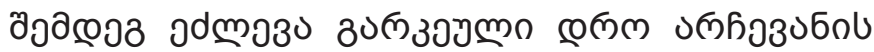

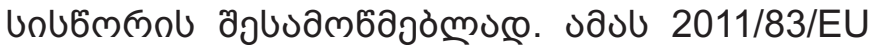

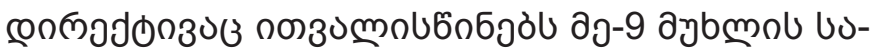

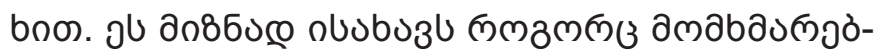
mol oु

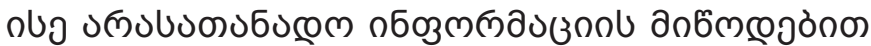

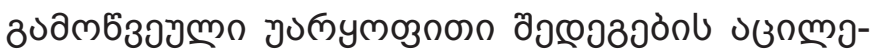

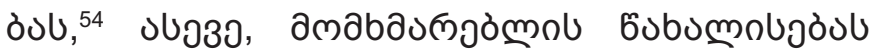

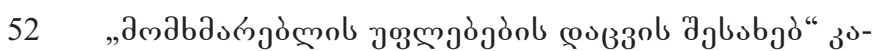

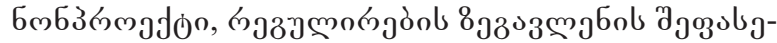
do - RIA, 2019.

53 of $39,33.58$

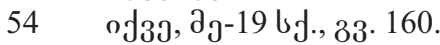




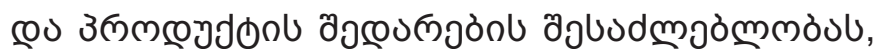

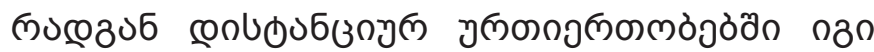

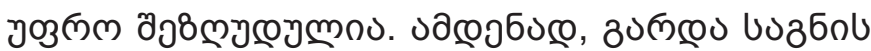

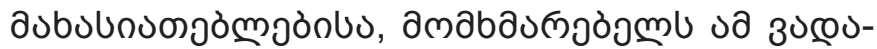

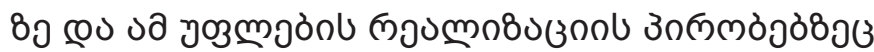

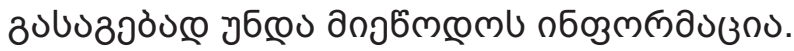

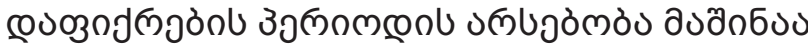

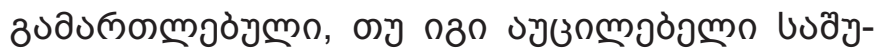

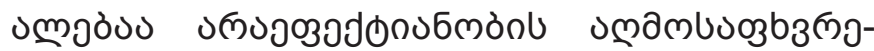

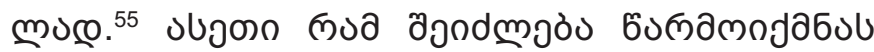

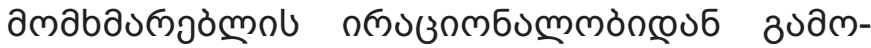

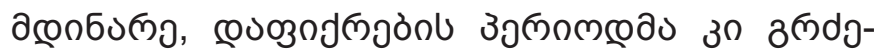

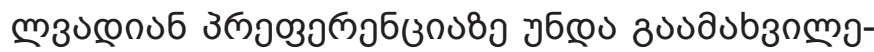

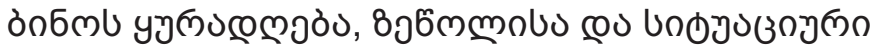

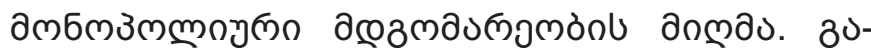

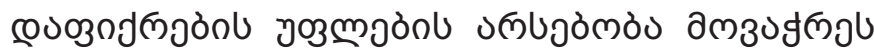

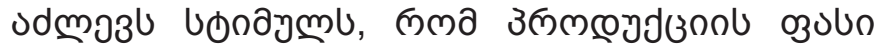

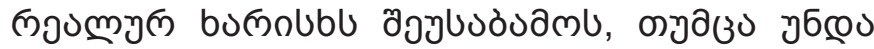

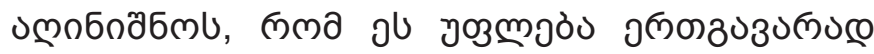

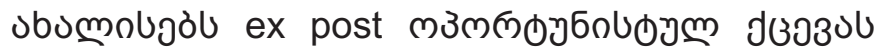

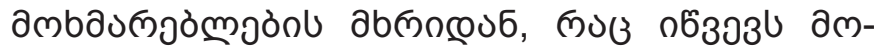

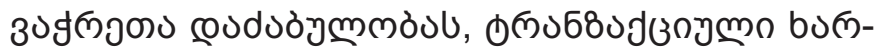

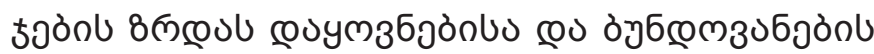
ठेวल. ${ }^{56}$

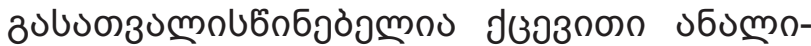

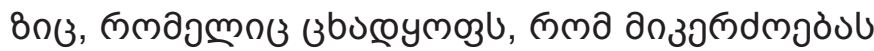

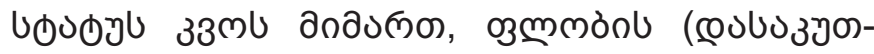

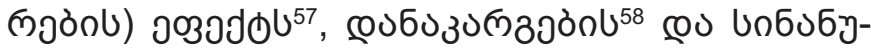

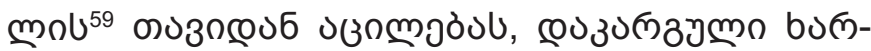

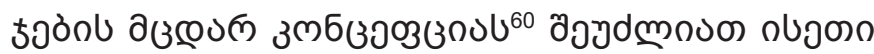

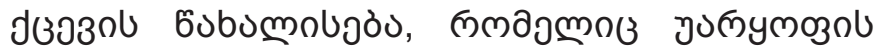

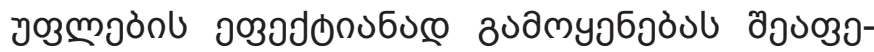

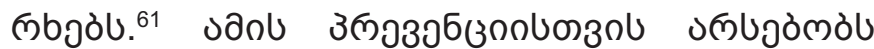

of39, 37-g bf., 33.1147

of39, 33.1149.

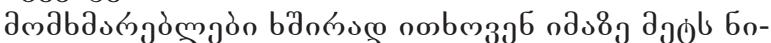

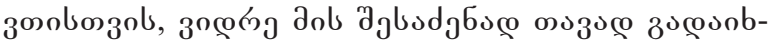

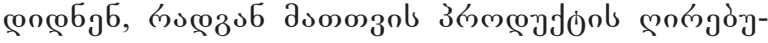

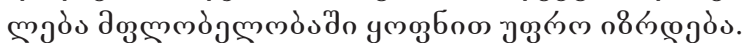

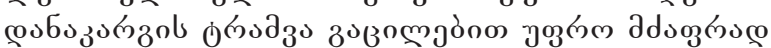

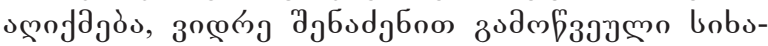
бymo. ob. Kahneman, D., Tversky, A., 1979. Prospect theory: An analysis of decision under risk, Vol. 47, The Econometric Society, pp. 263-291.

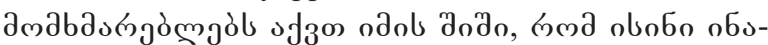

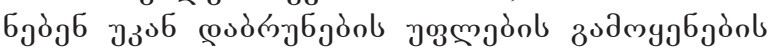

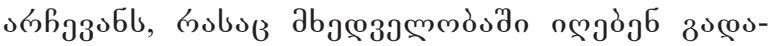

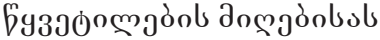

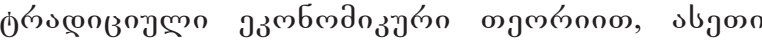

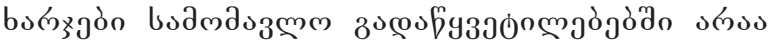

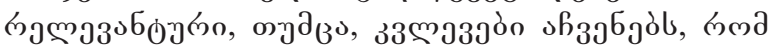

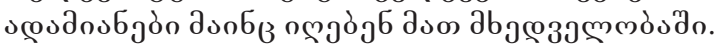

61

Tscherner, E.M., 2014. Can behavioral research advance

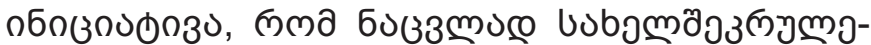

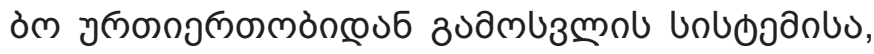

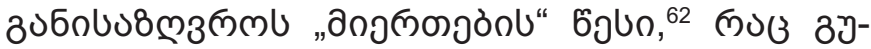

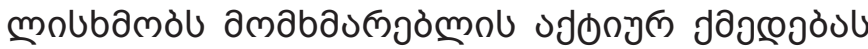

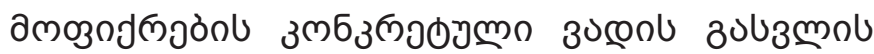

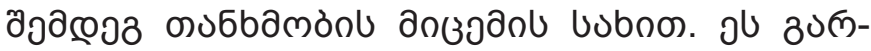

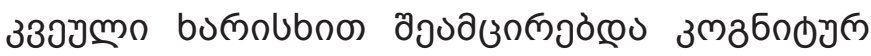

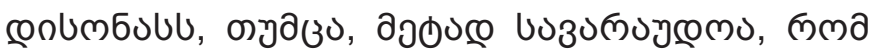

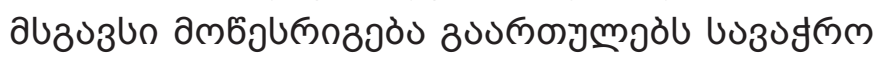

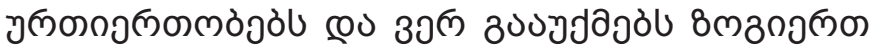

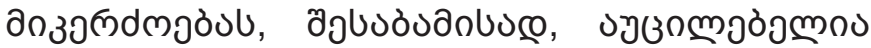

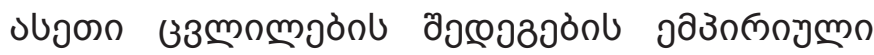
ззмозง.

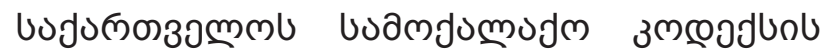

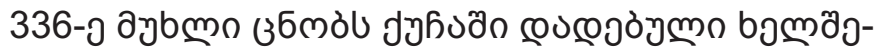

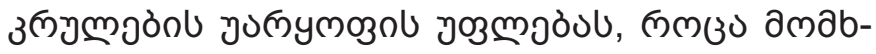

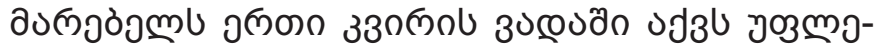

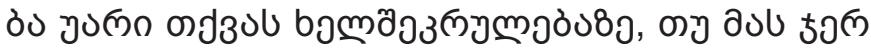

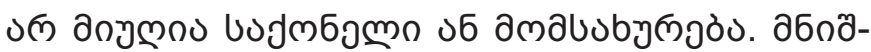

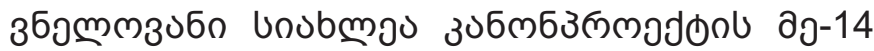

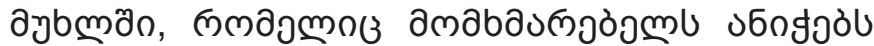

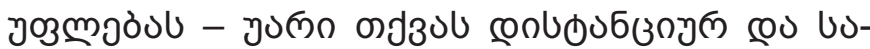

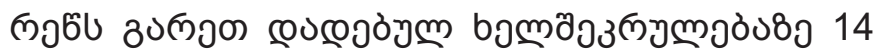

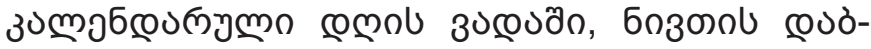

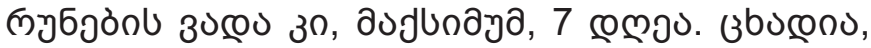

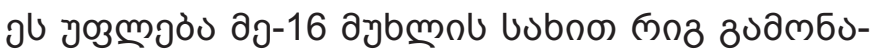

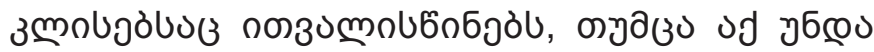

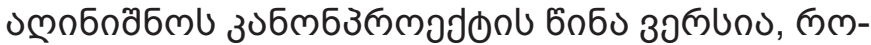

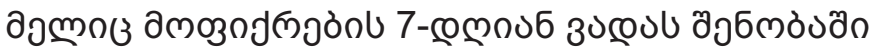

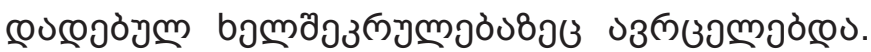

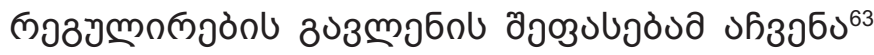

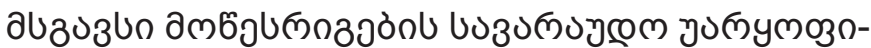

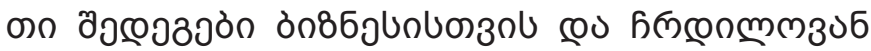

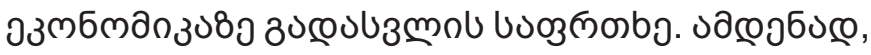

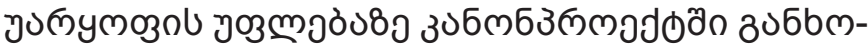

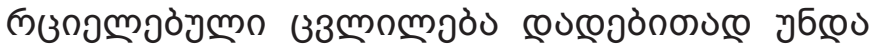

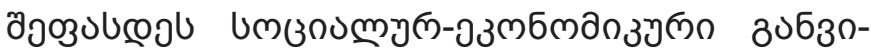

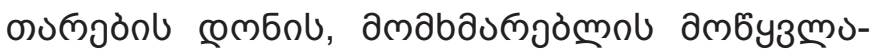

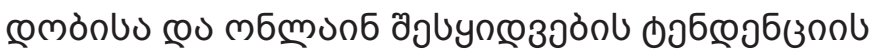

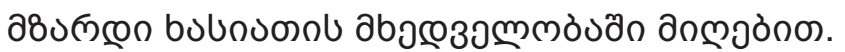

mandatory law, information duties, standard terms and withdrawal rights? Austrian Law Journal, p. 155.

62 of39, 154. ১bว39, Harrison, P., 2016. Cooling-off periods for consumers don't work: study https://theconversation. com/cooling-off-periods-for-consumers-dont-workstudy-69473 [оेммм бзгодл: 26.10.2021]

63 э.. . RIA, http://www.moesd.gov.ge/uploads/publications/ economy_450476725899caab552165.56302821.pdf [оेмммм бзюмдљ: 26.10.2021]. 


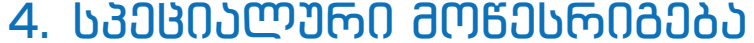

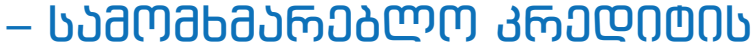

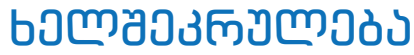

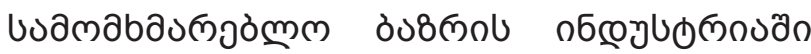

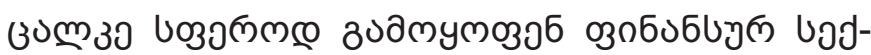

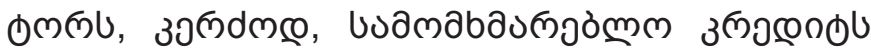

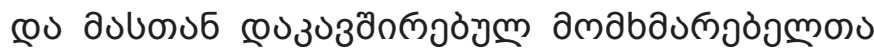

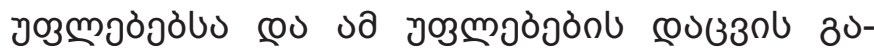

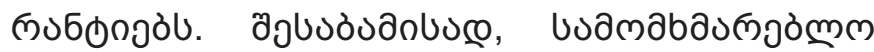

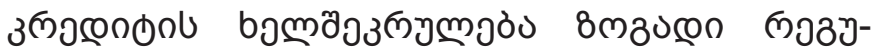

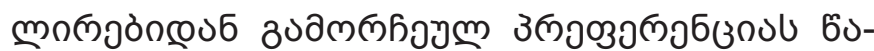

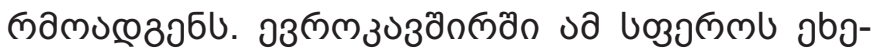

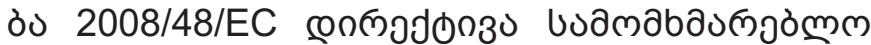

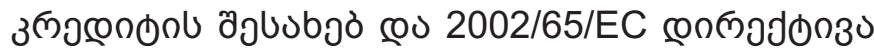

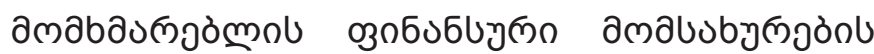

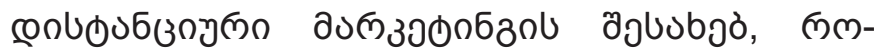

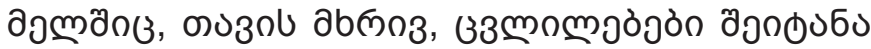

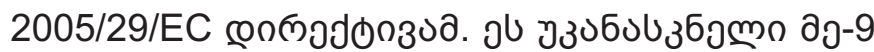

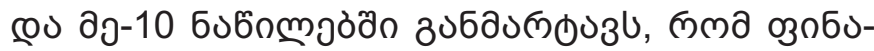

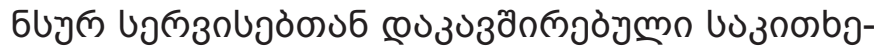

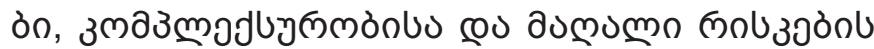

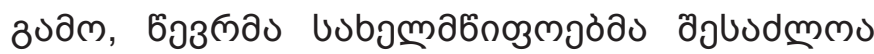

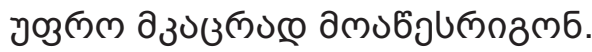

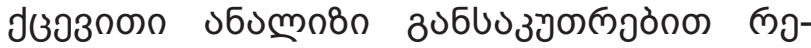

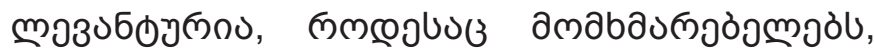

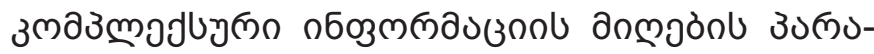

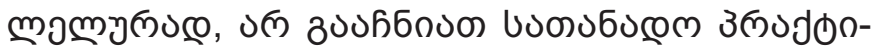

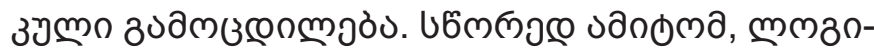

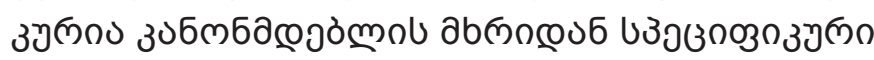

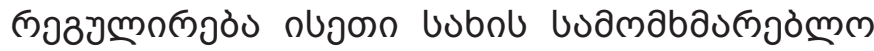

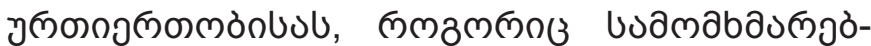

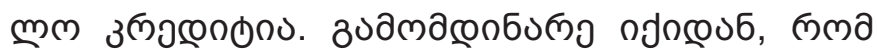

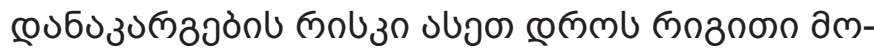

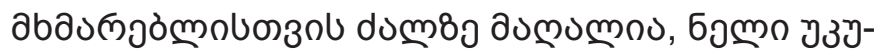

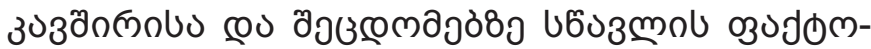

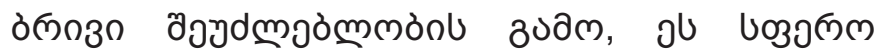

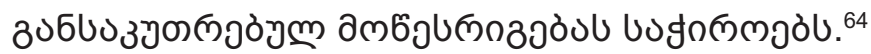

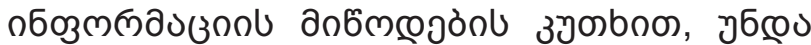

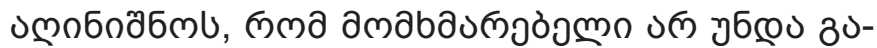

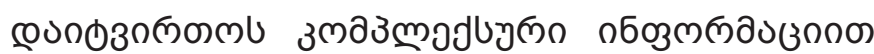

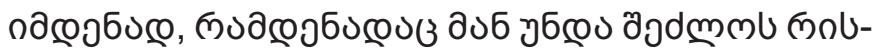

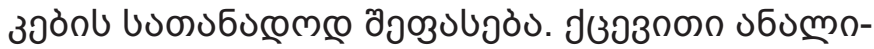

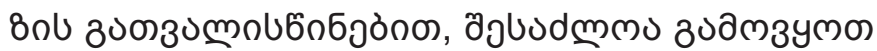

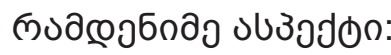

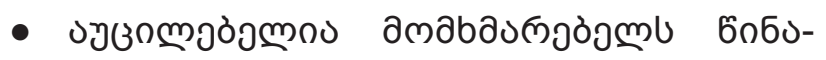

64 Juurikkala, O., 2013. The New Legal Paternalism: LightTouch Regulation for Consumer Mortgages, Helsinki Law Review, 7, pp. 55-84, p. 58.

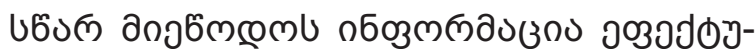

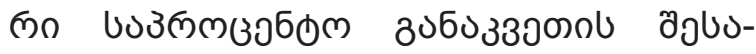

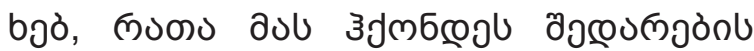

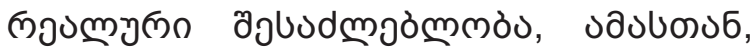

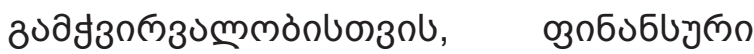

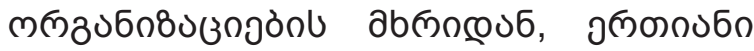

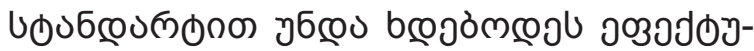

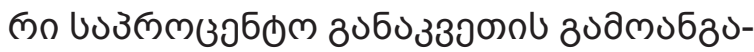

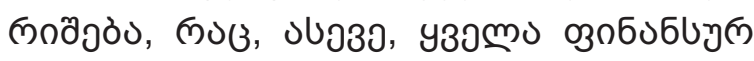

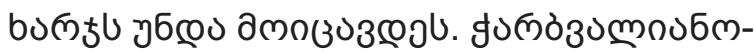

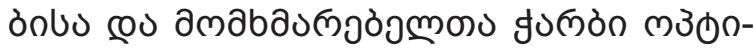

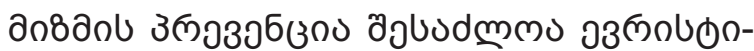

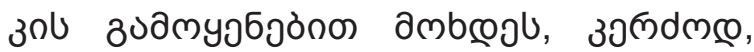

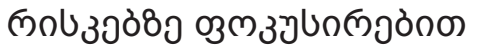

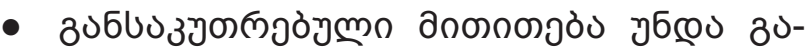

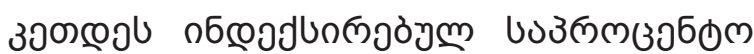

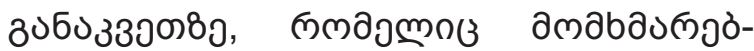

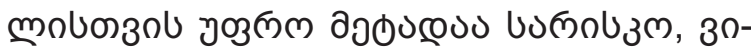

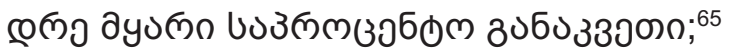

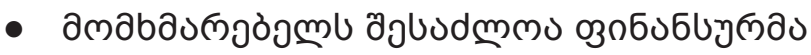

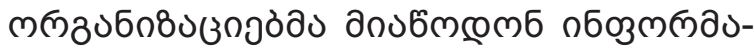

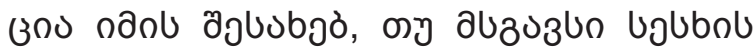

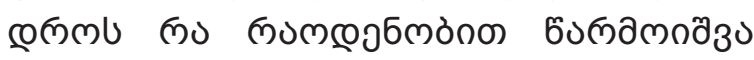

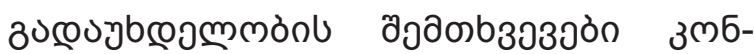

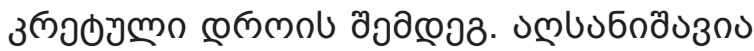

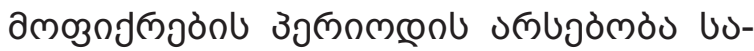

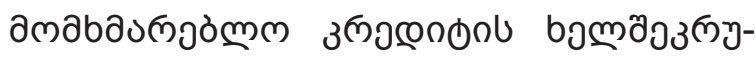

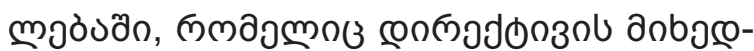

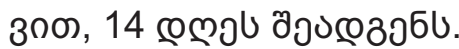

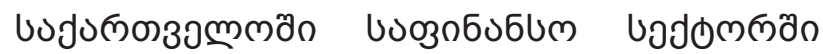

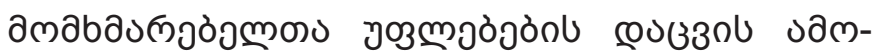

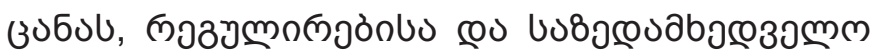

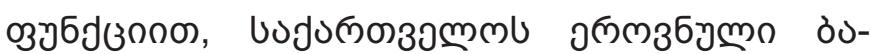

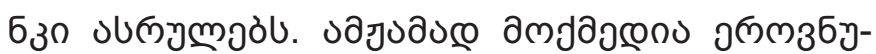

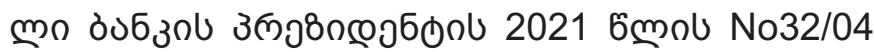

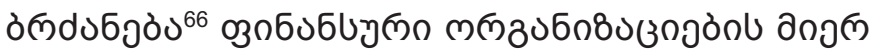

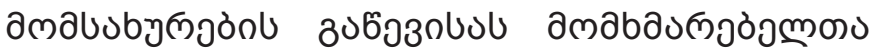

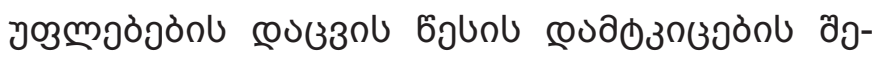

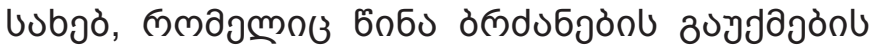

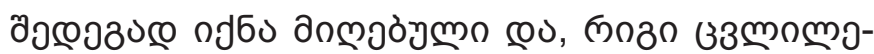

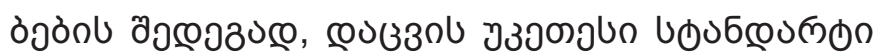

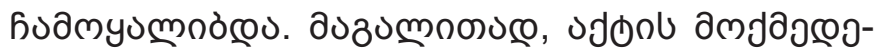

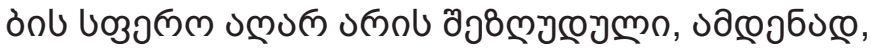

65 คป3ว, 33.83.

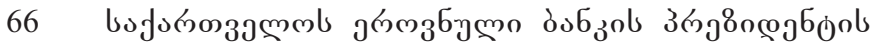

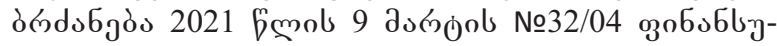

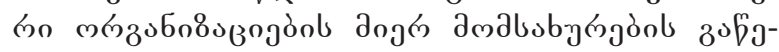

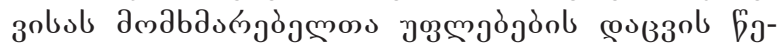

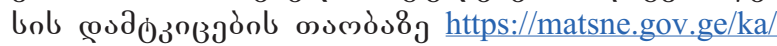
document/view/5117792? publication=0\#DOCUMENT:1 


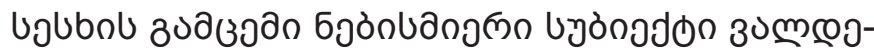

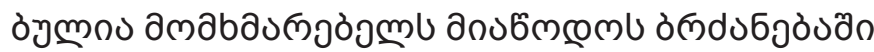

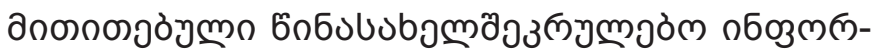

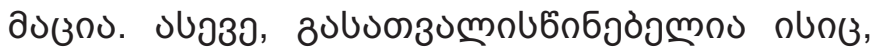

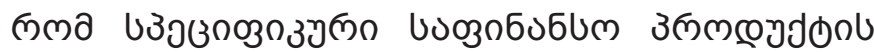

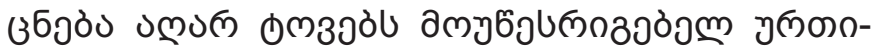

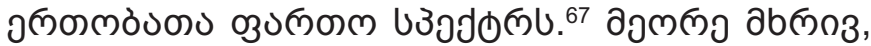

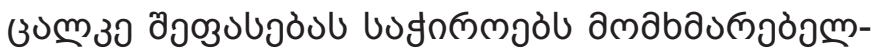

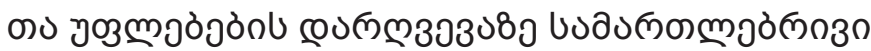

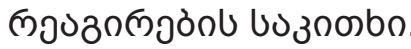

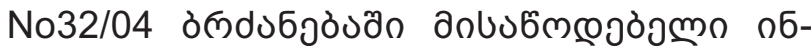

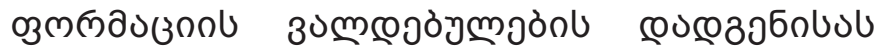

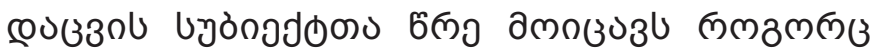

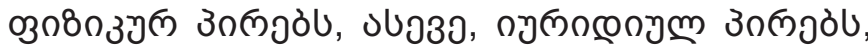

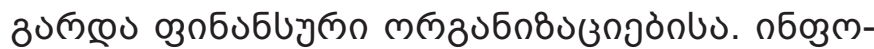

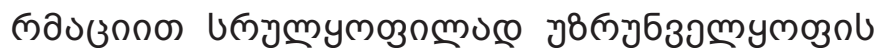

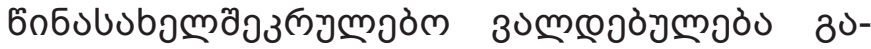

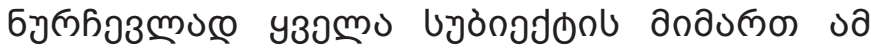

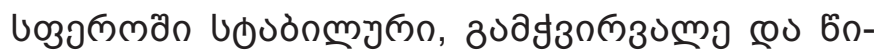

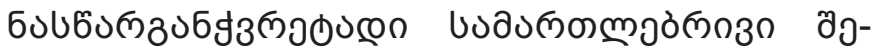

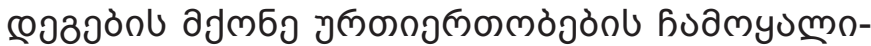

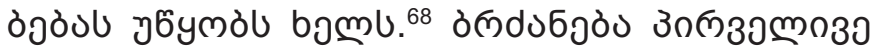

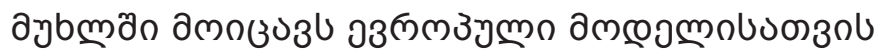

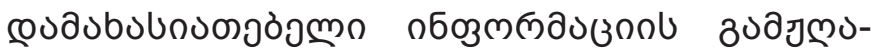

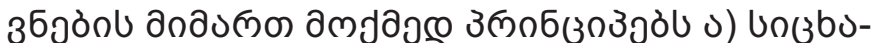

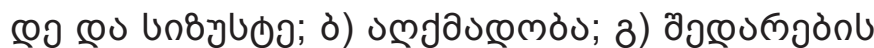

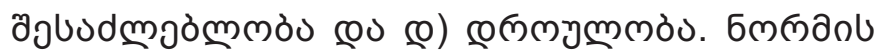

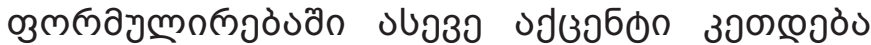

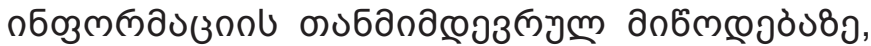

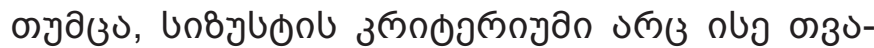

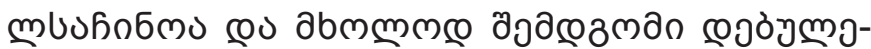

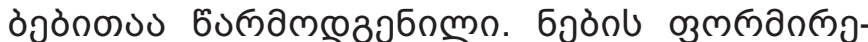

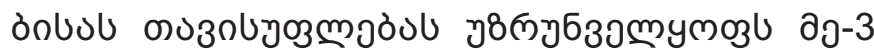

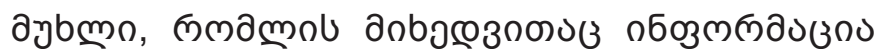

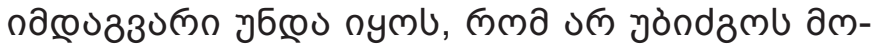

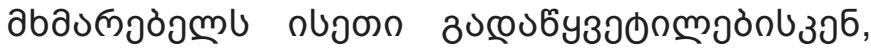

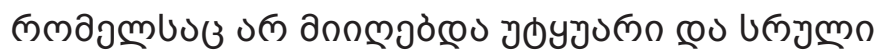

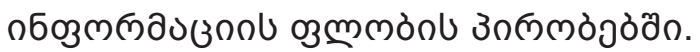

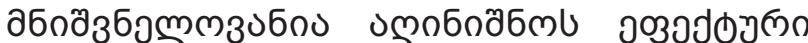

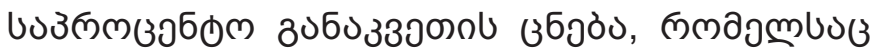

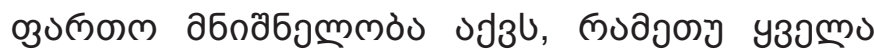

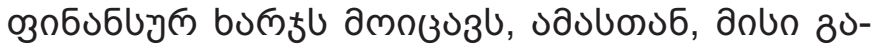

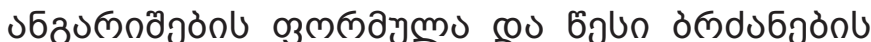

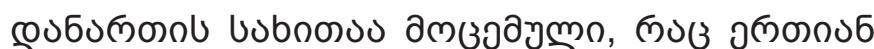

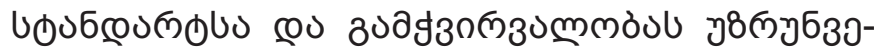

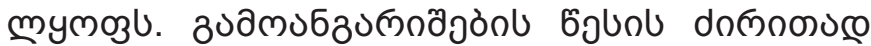

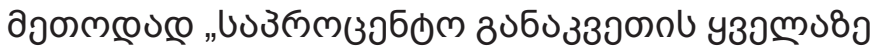

67 ob. $\partial y b$ mo 2 (6).

68 od39, 27-g bf., 33. 113.

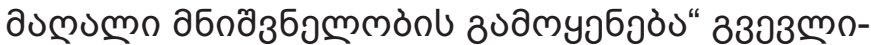

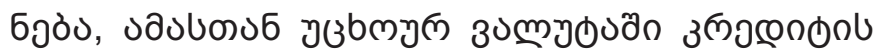

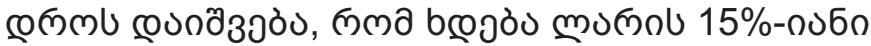

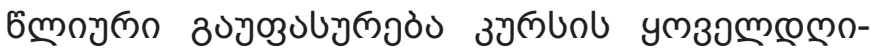

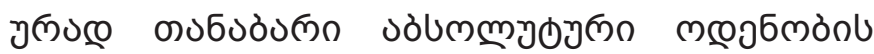

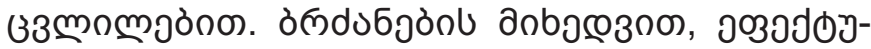

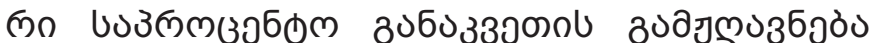

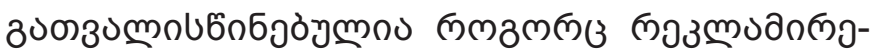

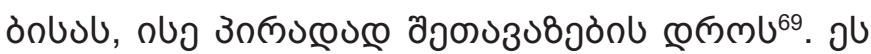

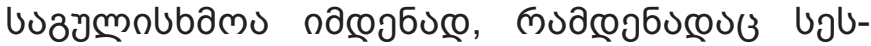

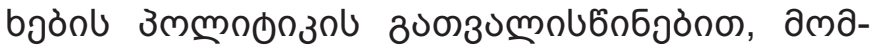

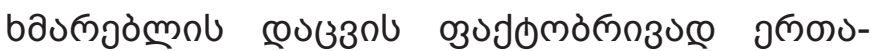

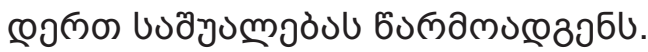

৬১алмо

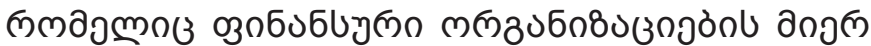

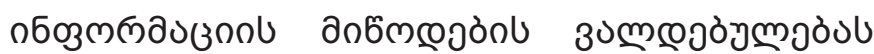

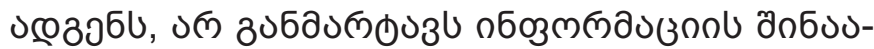

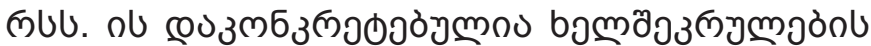

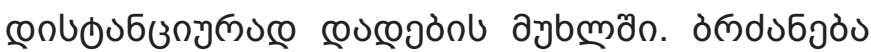

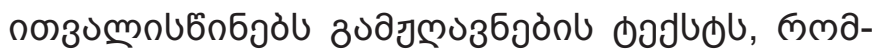

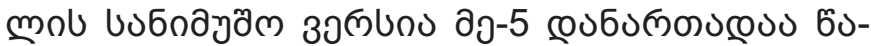

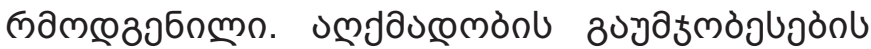

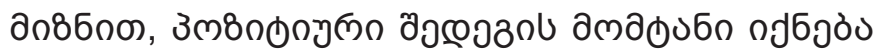

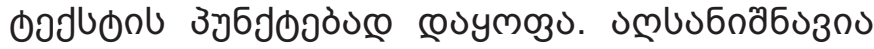

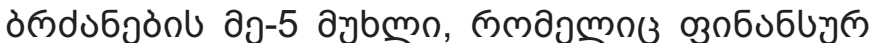

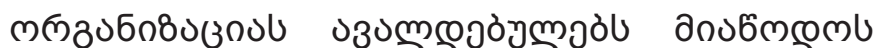

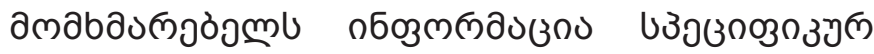

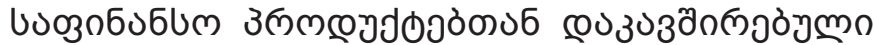

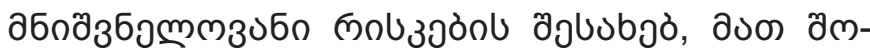

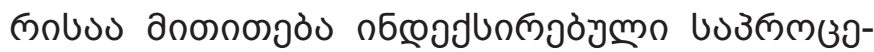
бом 3060330mol mob $380^{70}$.

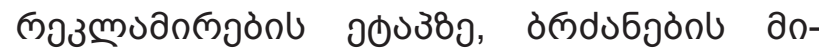

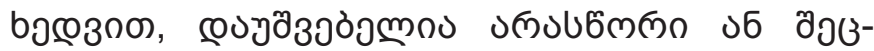

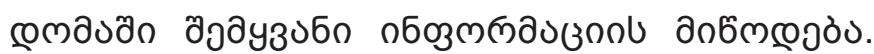

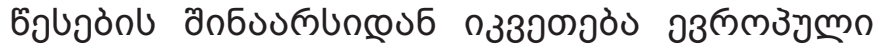

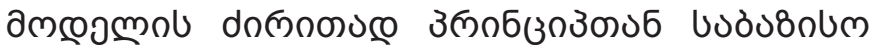

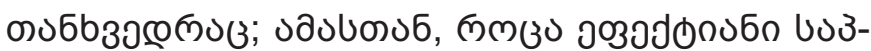

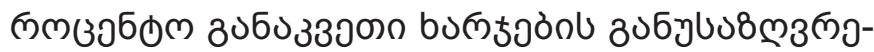

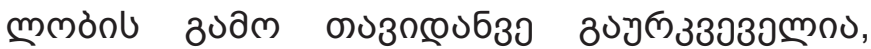

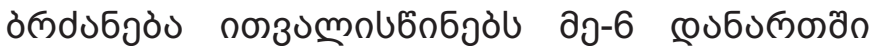

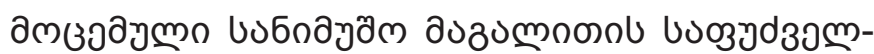

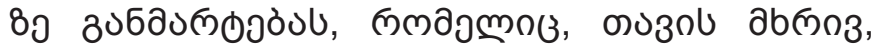

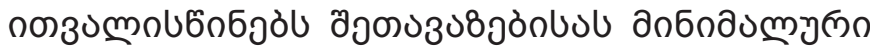

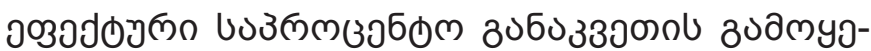

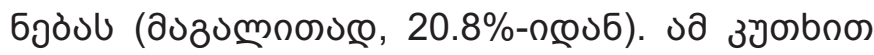

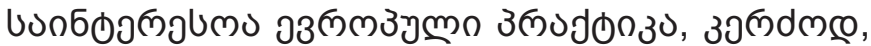

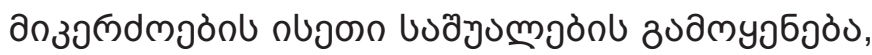

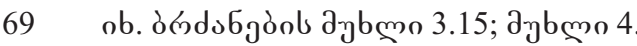

70 ob. Әybmo 5.3 . 


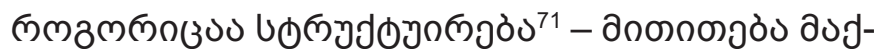

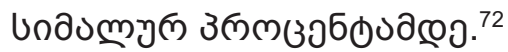

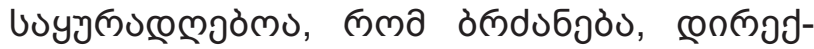

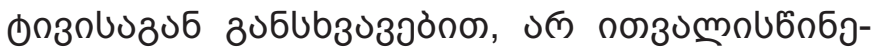

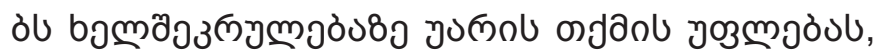

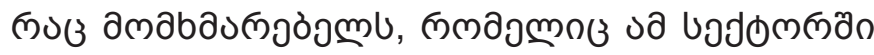

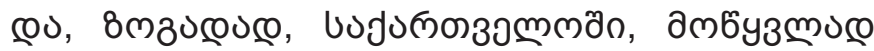

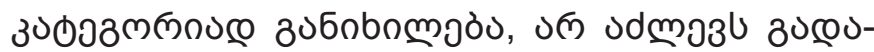

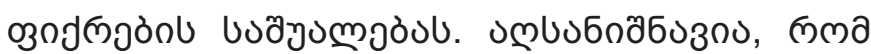

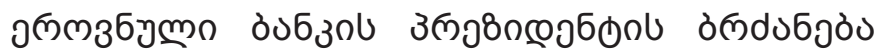

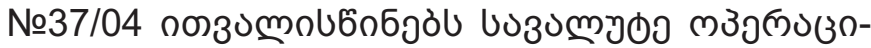

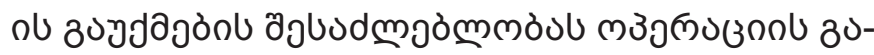

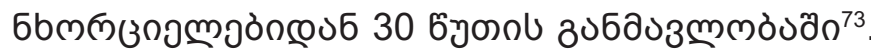

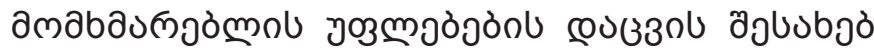

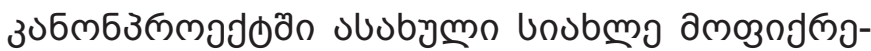

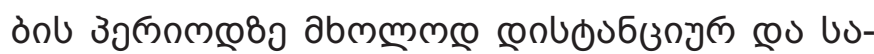

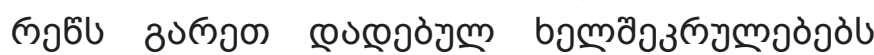

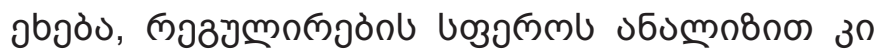

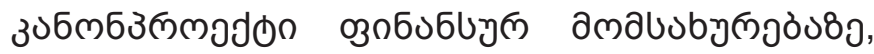

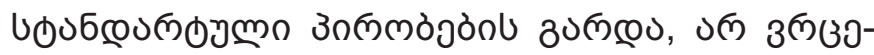

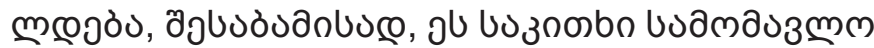

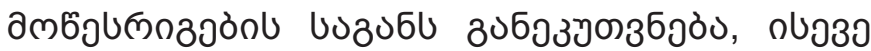

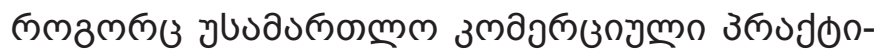

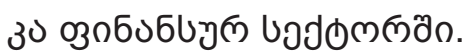

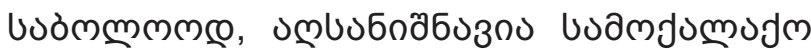

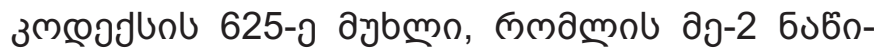

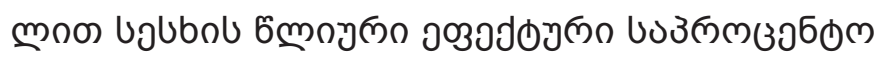

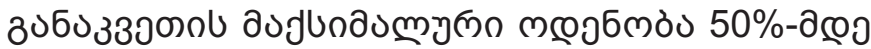

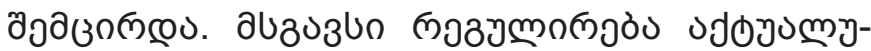

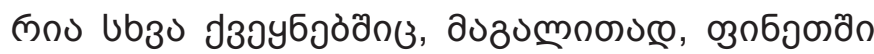

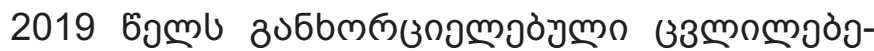

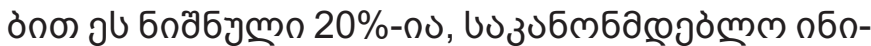

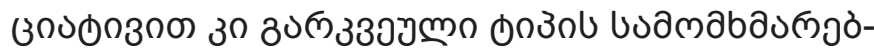

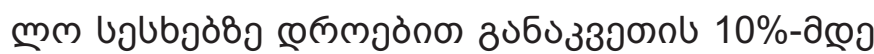

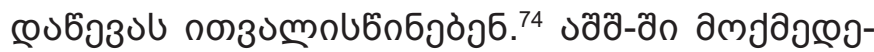

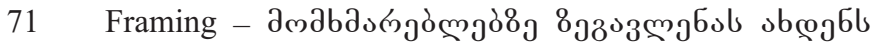

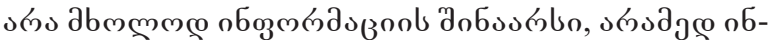

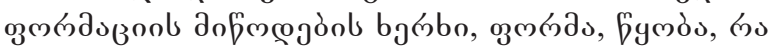

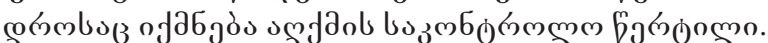
Behavioural Insights Applied to Policy, European Report 2016, pp. 20-21. https://publications.jrc.ec.europa.eu/ repository/bitstream/JRC100146/kjna27726enn_new.pdf

https://matsne.gov.ge/ka/document/

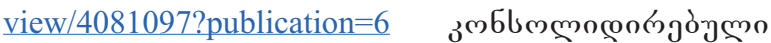

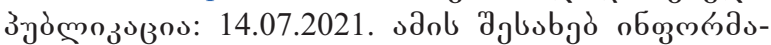

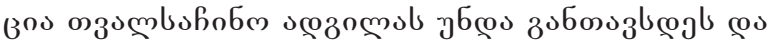
dogmommb f3omsk8

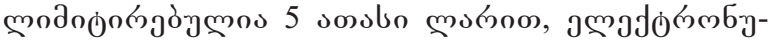

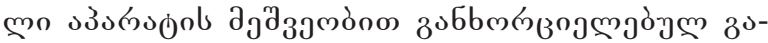

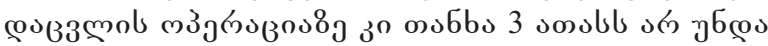

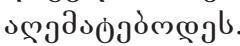

ob Credit Card Accountability Responsibility and

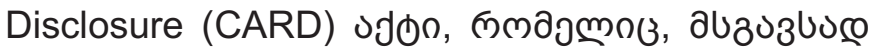

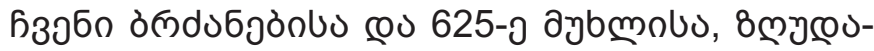

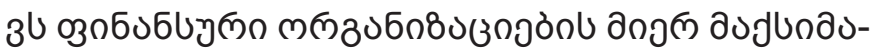

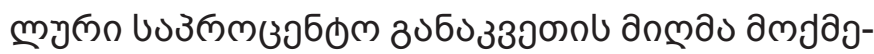

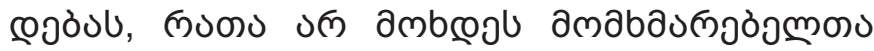

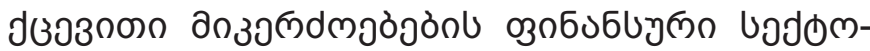

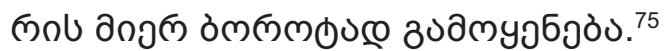

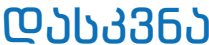

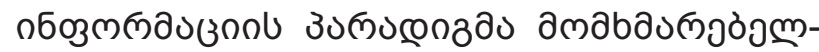

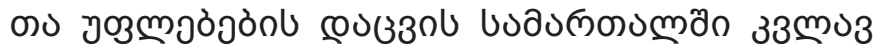

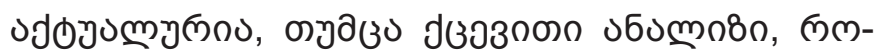

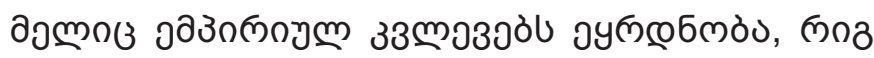

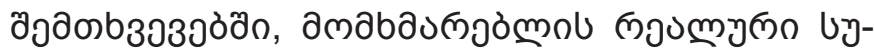

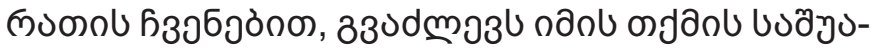

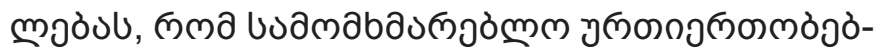

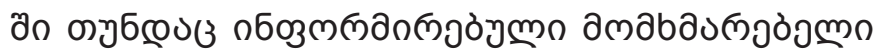

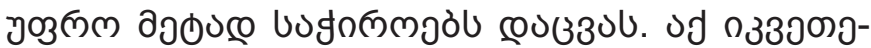

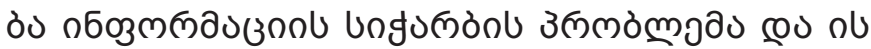

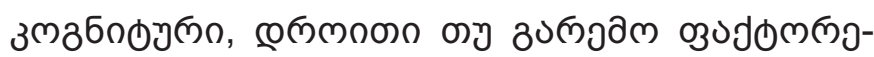

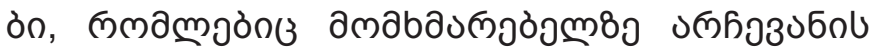

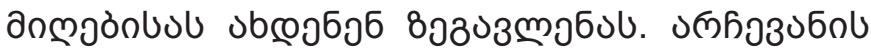

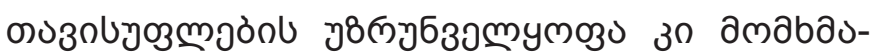

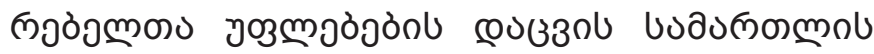

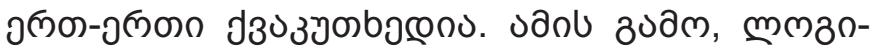

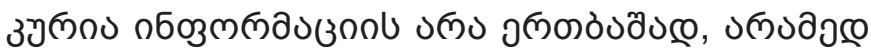

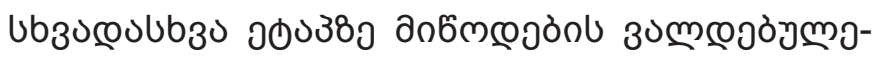

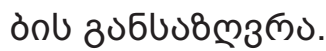

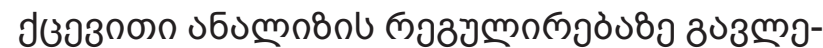

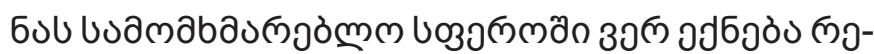

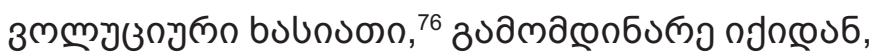

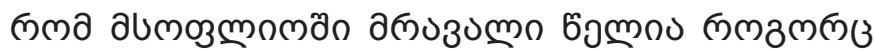

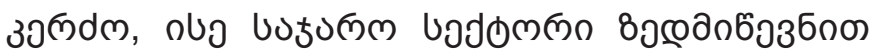

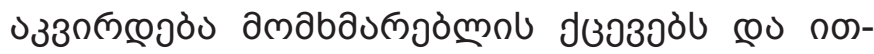

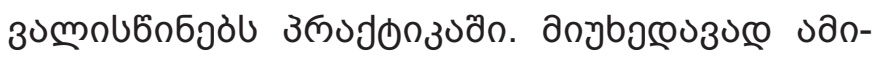

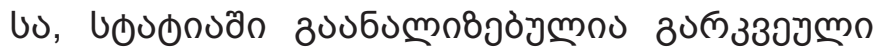

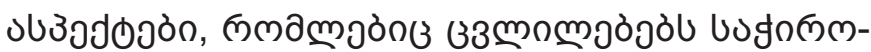

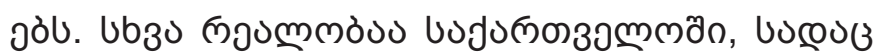

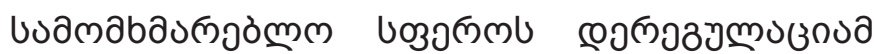

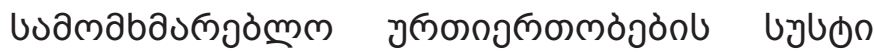

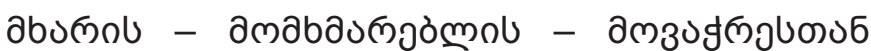

rates and direct marketing of consumer loans https://www. ww.fi/news/2020/04/new-temporary-restrictions-oninterest-rates-and-direct-marketing-of-consumer-loans/ [оेммм бзґмдљ: 26.10.2021].

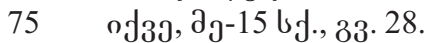

76 od3ว, วð-7 ๒f., 33. 212. 


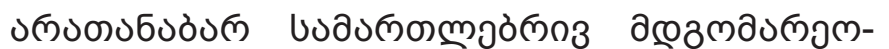

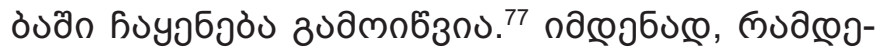

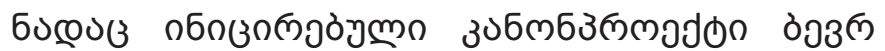

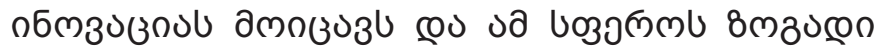

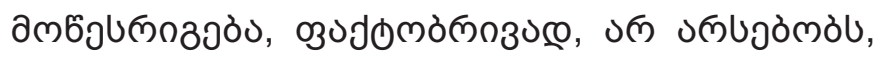

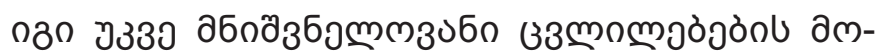

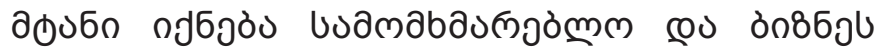

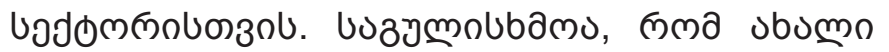

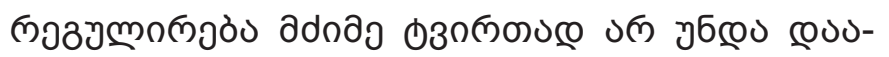

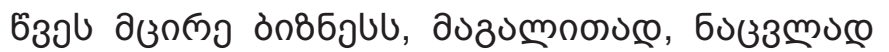

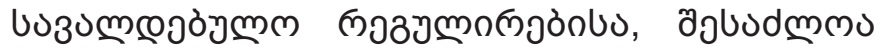

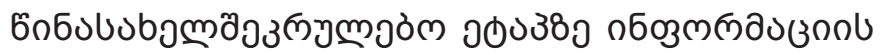

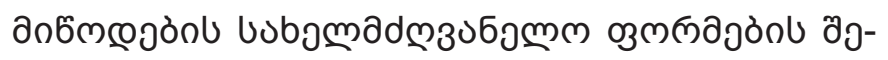

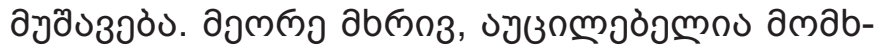

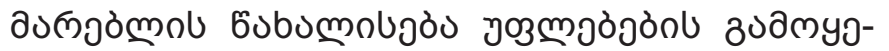

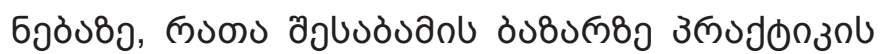

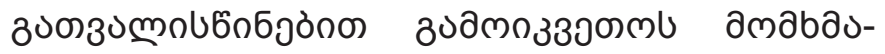

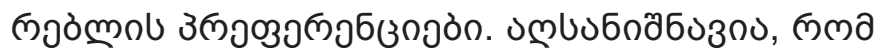

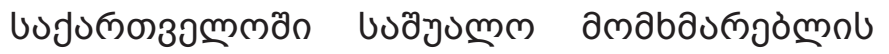

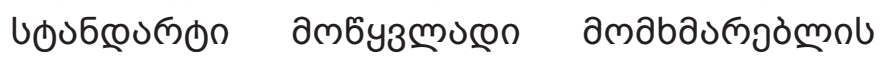

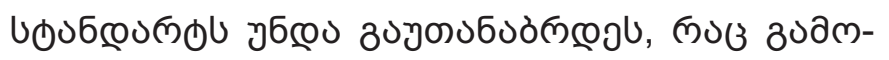

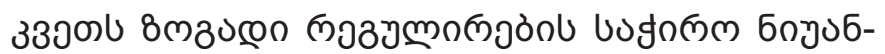

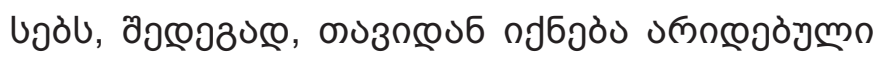

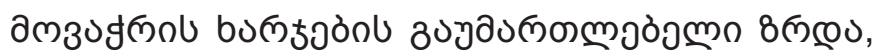

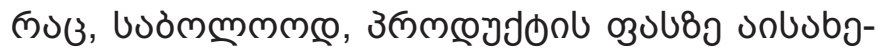

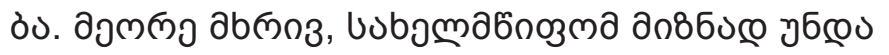

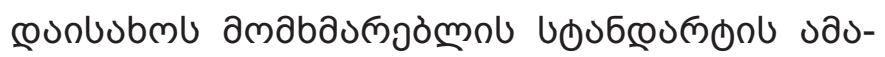

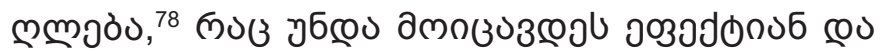

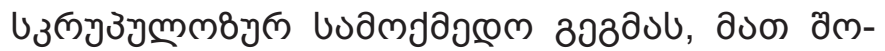

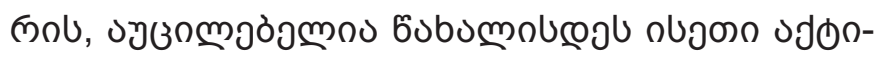

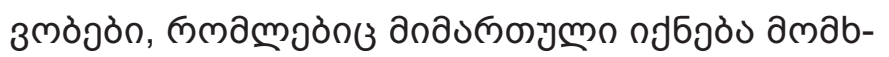

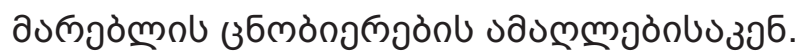

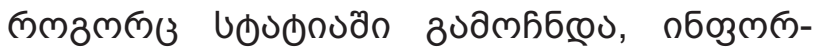

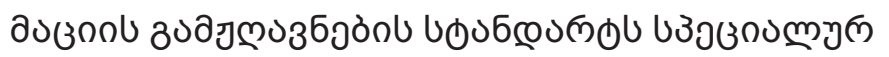

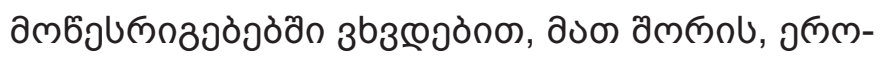

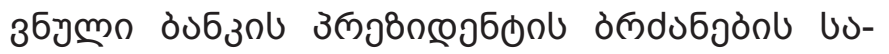

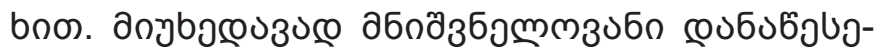

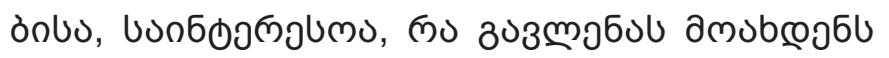

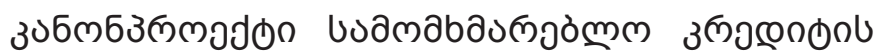

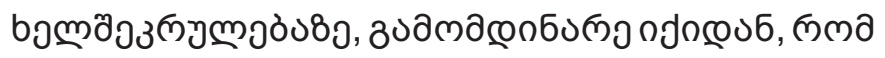

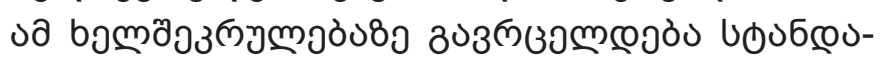

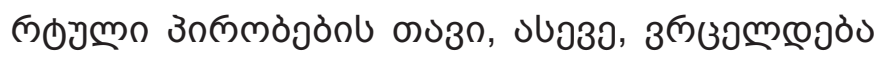

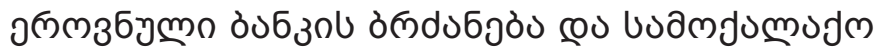

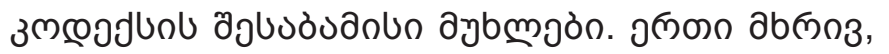

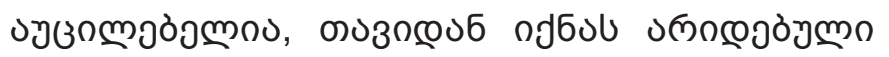

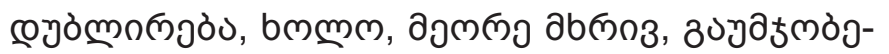

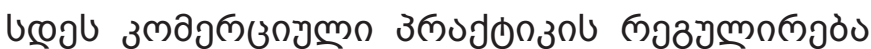

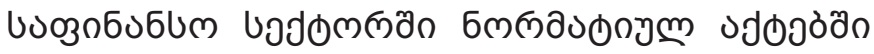

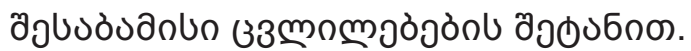

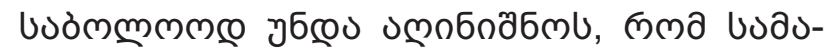

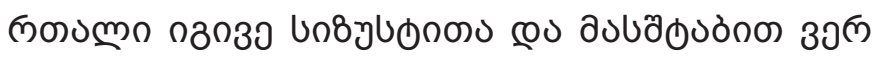

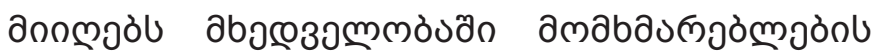

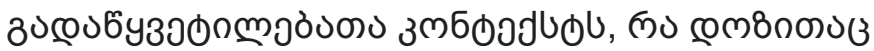

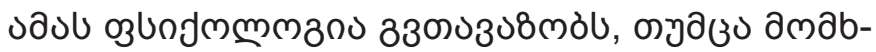

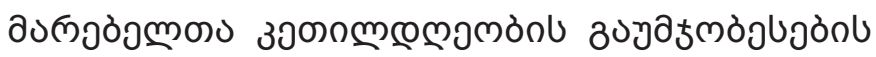

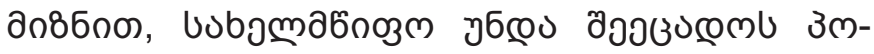

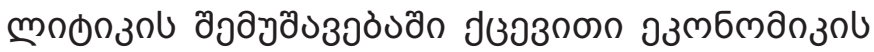

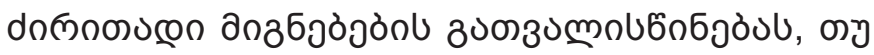

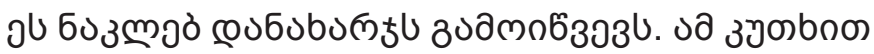

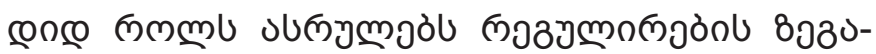

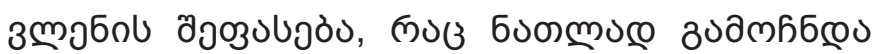

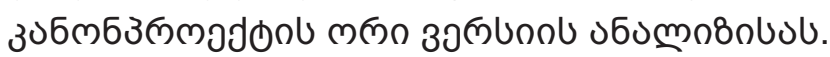

77 od39, $52-3$ bf., 33.4.

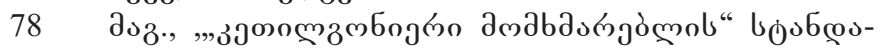

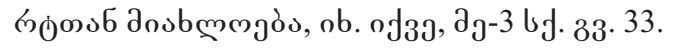

